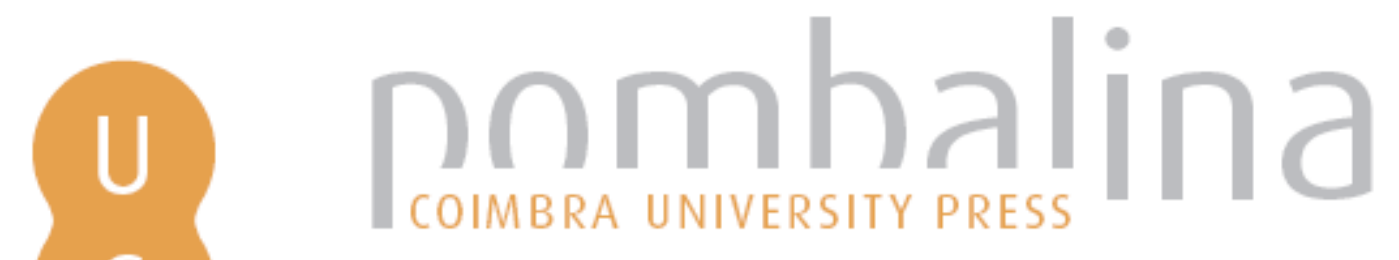

\title{
Fosso do médio Zêzere: um livro aberto de geomorfologia
}

Autor(es): Lourenço, Luciano

Publicado por: Imprensa da Universidade de Coimbra

URL

persistente: URI:http://hdl.handle.net/10316.2/43480

DOI: $\quad$ DOI:https://doi.org/10.14195/978-989-26-1343-7_10

Accessed : $\quad$ 26-Apr-2023 10:16:21

A navegação consulta e descarregamento dos títulos inseridos nas Bibliotecas Digitais UC Digitalis, UC Pombalina e UC Impactum, pressupõem a aceitação plena e sem reservas dos Termos e Condições de Uso destas Bibliotecas Digitais, disponíveis em https://digitalis.uc.pt/pt-pt/termos.

Conforme exposto nos referidos Termos e Condições de Uso, o descarregamento de títulos de acesso restrito requer uma licença válida de autorização devendo o utilizador aceder ao(s) documento(s) a partir de um endereço de IP da instituição detentora da supramencionada licença.

Ao utilizador é apenas permitido o descarregamento para uso pessoal, pelo que o emprego do(s) título(s) descarregado(s) para outro fim, designadamente comercial, carece de autorização do respetivo autor ou editor da obra.

Na medida em que todas as obras da UC Digitalis se encontram protegidas pelo Código do Direito de Autor e Direitos Conexos e demais legislação aplicável, toda a cópia, parcial ou total, deste documento, nos casos em que é legalmente admitida, deverá conter ou fazer-se acompanhar por este aviso.

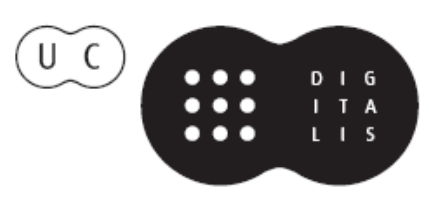




\section{FERNANDA CRAVIDÃO}

\section{IÚCIO CUNHA}

PAULA SANTANA

\section{NORBERTOSANTOS}

(ORG.)

\section{ESPAÇOS E TEMPOS EM GEOGRAFIA}

HOMENAGEM A ANTÓNIO GAMA

IMPRENISA DÁ UNIVERSIDADE DE COIMBRA COIMBRA UNIVERSITY PRESS

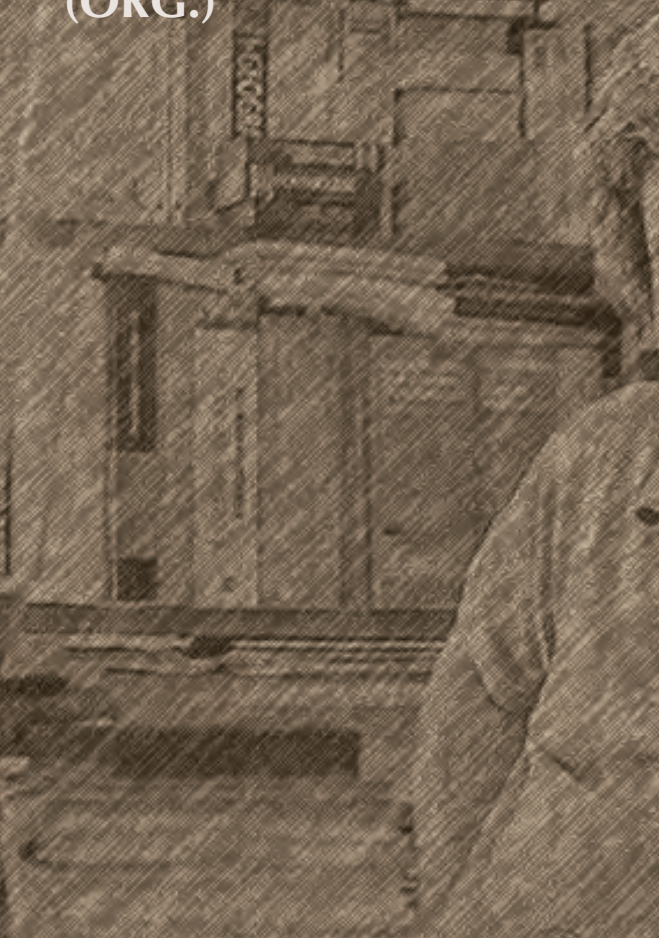




\title{
FOSSO DO MÉDIO ZÊZERE. UM LIVRO ABERTO DE GEOMORFOLOGIA
}

\author{
Luciano Lourenço/luciano@uc.pt \\ Departamento de Geografia e Turismo e CEGOT. \\ Faculdade de Letras da Universidade de Coimbra
}

\section{Introduçáo}

Depois de alguma hesitação sobre o tema que deveria apresentar neste livro dedicado ao colega António Gama Mendes, entendi que não poderia ser outro que não o vale do Zêzere, dado que não só o homenageado dele era natural, mas também porque dediquei algum do meu tempo ao estudo da geomorfologia desse vale, já lá vão alguns anos (Lourenço, 1996), e não quis perder esta oportunidade para retomar o assunto, centrando-me numa área geográfica que era particularmente querida ao António Gama.

Como seu aluno em três unidades curriculares de Geografia Humana, recordo as suas magistrais aulas teóricas, que a todos marcavam de forma indelével, mas guardo particular memória do seu gosto pela Geografia Física e, em especial, de uma viagem de estudo, já náo recordo qual o contexto nem a unidade curricular em que ela se realizou, apenas retenho na memória que o Gama Mendes nela participou e, eis senão quando, no alto da serra do Açor, tendo-se parado o Velho Land Rover para observação de uma plantação de vidoeiros (Betula alba), ele se concentra numa pequena barreira da berma da estrada e no depósito que nela era visível, o qual servia de substrato a essa plantação, e nos questiona 
sobre uma matéria de que ainda nem sequer tínhamos ouvido falar, os depósitos periglaciares, e aproveitando o ensejo, nos brindou com uma excelente dissertação sobre a formaçã̃o e as caraterísticas desse tipo de depósitos.

Apesar do tempo que transcorreu desde então, fazendo contas verifico que tal sucedeu haverá uns quarenta anos, mas recordo como se fosse hoje, a sua posição na barreira e a sua postura durante a explicação, algo que me fascinou e não esquecerei, dada a vivacidade e clareza dessa intervençáo, bem como a surpresa que me causou o seu aprofundado domínio deste tema da geografia física, dado que ele era nosso professor da área da geografia humana, embora mais tarde tivesse comprovado que, afinal, este era, apenas, um dos muitos temas que dominava na geografia física.

Porque o vale do Zêzere permite retomar essa problemática e tratar não só uma área que dizia muito ao António Gama, com quem aliás troquei muita informação sobre ela, mas também porque possibilita fazer um referência aos depósitos periglaciares que me foram dados a conhecer, em primeira mão, pelo Gama Mendes, não encontrei melhor forma de o homenagear que não fosse centrar-me na área que o viu nascer.

\section{Objetivos e metodologia}

O objetivo deste texto visa apresentar, de forma condensada, alguns aspetos que se prendem com a caracterização geomorfológica daquilo a que Orlando Ribeiro (1949) chamou o "fosso do médio Zêzere", o que denota bem a importância da tectónica na delimitação desse fosso, estando essa movimentação tectónica muito bem testemunhada nas cristas quartzíticas que o atravessam, conforme procuraremos demonstrar.

Um segundo objetivo está relacionado com a formação dos célebres meandros do Zêzere, uns claramente adaptados à estrutura e à fraturaçáo, enquanto outros parecem intimamente ligados a dificuldades na travessia das cristas.

O terceiro e último dos objetivos passa pela apresentação dos principais tipos de depósitos de vertente que se encontram no médio Zêzere, com descrição das 
suas principais características e identificação das condiçôes climáticas subjacentes à respetiva formação, bem como do seu posicionamento relativo.

No que concerne à metodologia, privilegiou-se o trabalho de campo a que se seguiu intenso trabalho de gabinete, para tratamento cartográfico e laboratorial, como se descreveu pormenorizadamente na obra anteriormente citada (Lourenço, 1996).

A área que pretendemos aqui destacar, situa-se dentro daquela que constitui o fosso do médio Zêzere (Figura 1), corresponde sensivelmente aos seus 2/3 iniciais, aqueles onde o Zêzere deixa a Cova da Beira para se encaixar por entre formaçôes metassedimentares e que, genericamente, está compreendida entre a confluência da Ribeira do Paúl, embora só se acentue após a confluência da ribeira do Porsim, e o plutonito de Pedrógão Grande, situado a jusante, a partir do qual as características do vale se modificam.

\section{A tectónica como condicionante das formas de relevo}

O fosso do médio Zêzere aparece muito bem delimitado a Noroeste, onde é possível seguir, em praticamente toda a sua extensão, a falha de Cebola, pela primeira vez mencionada por Décio Thadeu (1949) e que separa, de forma muito clara (Fotografia 1), este fosso das designadas serras setentrionais.

Por sua vez, a Sueste, nem sempre é fácil identificar no campo, com a mesma clareza, as marcas da tectónica, em especial a Norte da serra de Alvelos, onde por vezes é difícil seguir a falha do Bravo, que é interrompida pela falha da Abitureira, a montante da qual o vale alarga, retomando a direção geral na falha de Bogas.

A quebrar a monotonia das formas arredondadas dos xistos desenvolvem-se duas cristas quartzíticas, transversais ao traçado do vale, que, comportando-se como soleiras de rocha dura, permitem testemunhar uma série de pequenas movimentaçôes no interior do fosso, paralelas a estes dois grande acidentes que o marginam. 


\section{Localização da área de estudo}

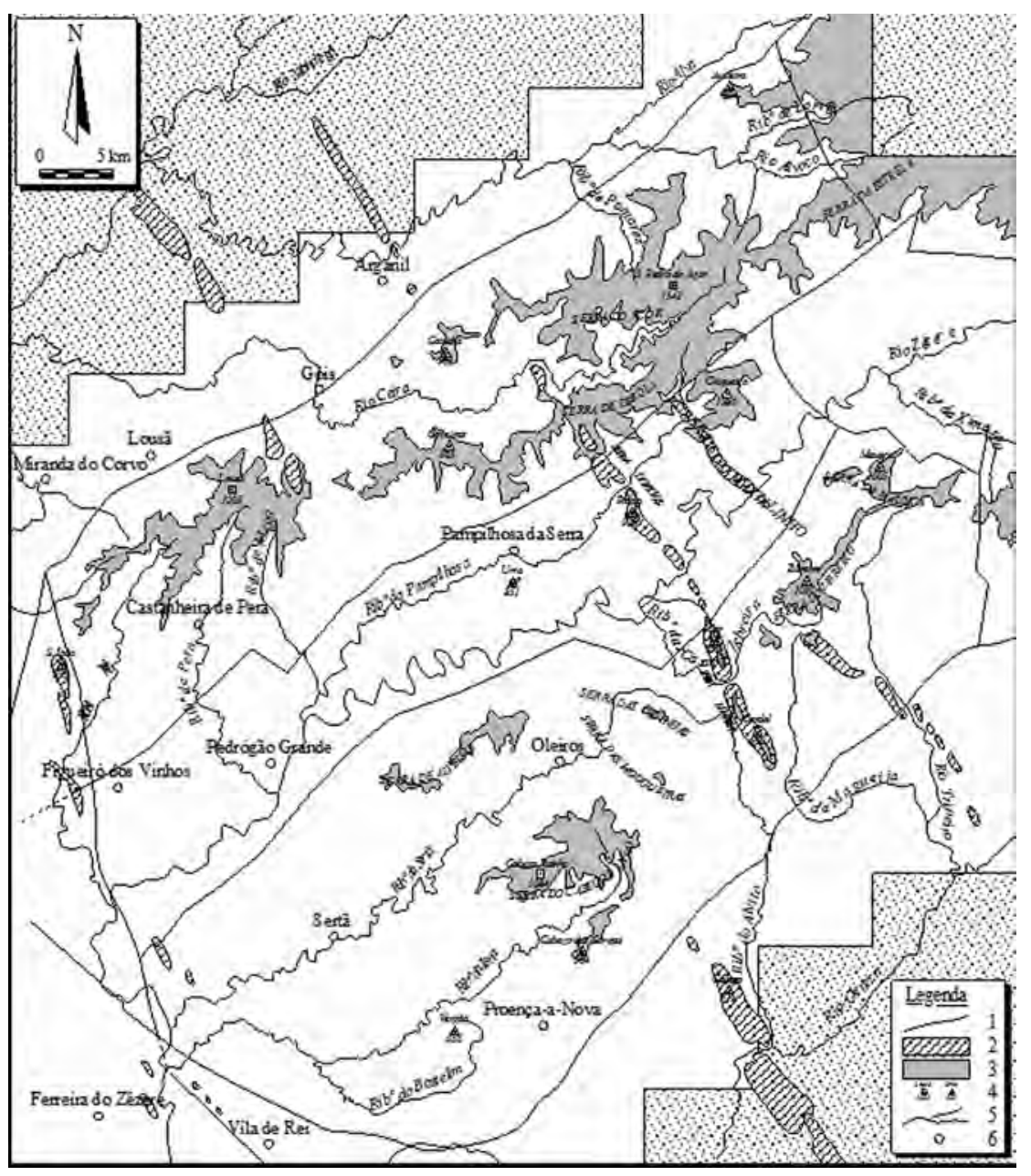

Figura 1

Esboço de localização do fosso do médio Zêzere, situado entre as serras de NW (Lousã, Caveiras, Cebola e Açor) e as de SE (Alvelos/Cabeço Rainho, Zibreiro e Maunça), com síntese interpretativa, muito simplificada, do relevo regional.

1 - falhas delimitando grandes unidades morfológicas; 2 - quartzitos; 3 - altitudes superiores a 800 metros; 4 - vértices geodésicos; 5 - rede hidrográfica;

6 - sedes de concelho 
Os alinhamentos quartzíticos que atravessam o vale do médio Zêzere são dois: a crista principal, que se estende dos Penedos de Fajão à serra do Muradal e, a secundária, que vai dos Penedos de Unhais-o-Velho ao Cabeço do Vale do Pereiro. Ambas apresentam uma orientação hercínica, ou seja, NW-SE. Os acidentes transversais, de direção NE-SW ou NNE-SSW, poderão ser mais antigos e, por conseguinte, terão ressoado posteriormente por diversas vezes.

\section{As cristas quartzíticas como testemunhas da movimentação tectónica}

Neste contexto, as cristas quartzíticas revelam-se um ótimo auxiliar para compreender o levantamento desses acidentes, constituindo mesmo um elemento fundamental para, através da movimentação refletida nas cristas, se deduzir a importância relativa das principais falhas, uma vez que nos xistos marginais essas manifestaçôes se degradam com muito mais facilidade, pelo que raramente se conservam por longos períodos.

Como as cristas quartzíticas permitem identificar, com alguma segurança, as características das movimentações relativas que foram sofrendo, procedemos ao levantamento dos perfis longitudinais dessas cristas, pois testemunham "as deformaçóes da superfície culminante da montanha, ela mesma derivada do arrasamento eocénico" (Daveau et al., 1985/6: 257).

Com efeito, o complexo jogo de blocos quartzíticos sente-se particularmente bem ao longo do alinhamento que dos Penedos de Fajão, nas serras setentrionais, se estende até ao Muradal, nas serras meridionais, atravessando o fosso tectónico do médio Zêzere, cujos limites não são coincidentes com os da bacia hidrográfica do rio Zêzere, e que encerra a chave para a explicação dessa movimentação, motivo pelo qual merece ser analisado com algum pormenor.

Assim, quem observa a crista quartzítica que, quase ininterruptamente, se estende de Fajão ao Muradal (Figura 2-C), não pode ficar indiferente à sua imponência. Por outro lado, a sua extensão permite que nela tenham ficado bem patentes as marcas deixadas pela atuação das diversas fases orogénicas e, sobretudo, que elas se encontrem ainda bem conservadas. 

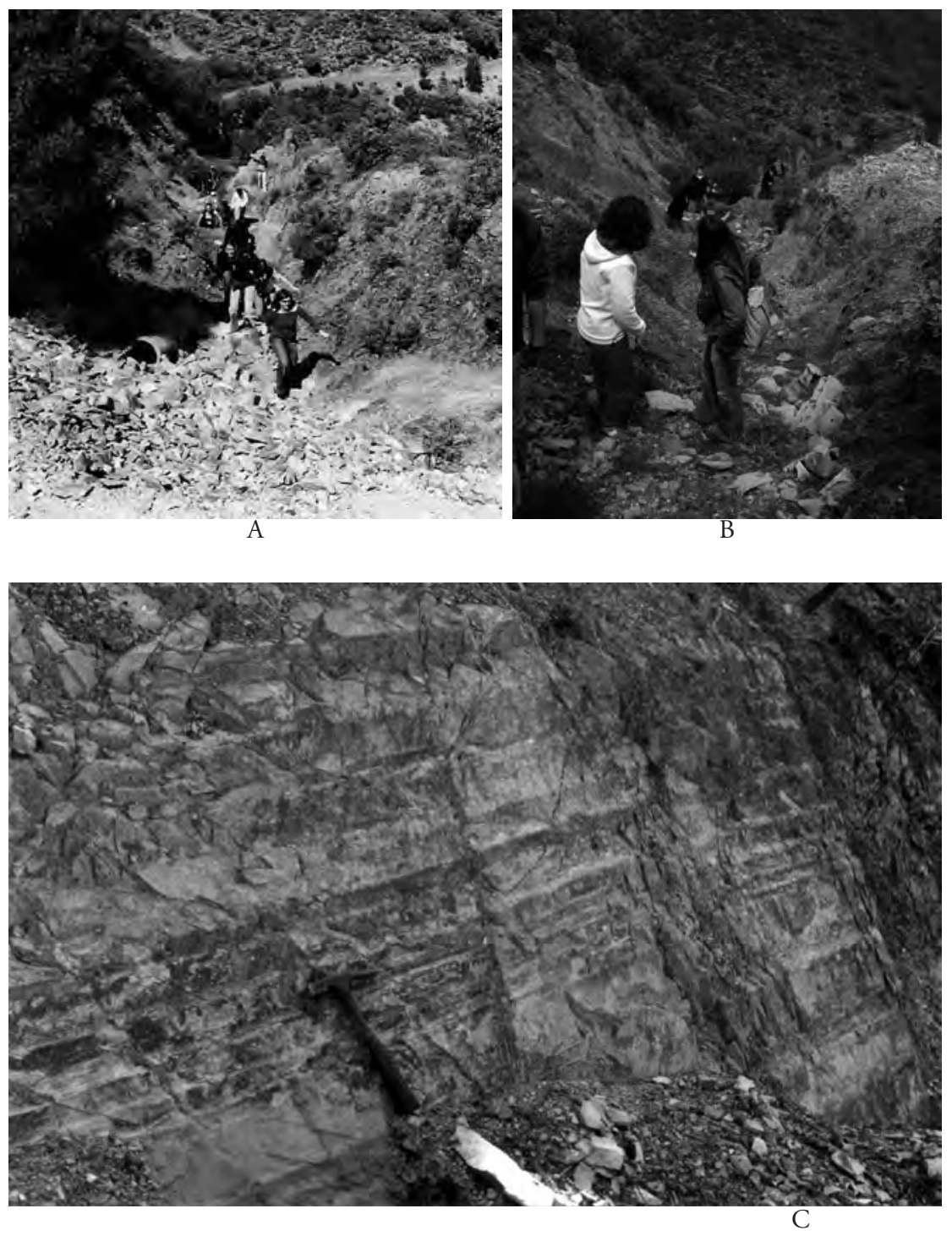

\section{Fotografia 1}

Vistas da falha de Cebola: A - Caixa de falha, a montante de São Jorge da Beira, tomada da divisória de águas. B - Aspeto de pormenor. C - Espelho de falha numa barreira da estrada Nacional 2, entre Louriceira e Mega Fundeira.

Fotografias de L. Lourenço 
O deslocamento de pequenos blocos é particularmente visível na área onde a crista é atravessada pelo rio Zêzere, a qual corresponde a um graben, dentro do qual se elevam dois horsts. Destes, o mais pequeno localiza-se a SE e origina os cabeços do Mosqueiro e do Vale do Pereiro, já situado na crista secundária (Figura 2-A) que se desenvolve a nascente. O outro, bastante mais complexo, proporciona as formas mais salientes e espetaculares, materializadas quer nos cabeços do Picoto e do Soito, quer na serra do Vidual, localizados respetivamente a Sul e a Norte do rio Unhais, o qual franqueia a crista através de um impressionante vale em garganta, que, por isso mesmo, foi aproveitado para a construção da barragem de Santa Luzia (Fotografia 2). Quando tal não acontece, as pequenas ribeiras despenham-se por espetaculares quedas de água (Fotografia 3).

Por sua vez, a crista secundária que se desenvolve neste setor, embora ligeiramente soerguida em relação à serra do Machialinho (Porta do Souto, $765 \mathrm{~m}$ ), apenas localmente, nos Penedos de Unhais $(885 \mathrm{~m})$, ganha alguma importância, pois as maiores altitudes encontram-se na serra do Chiqueiro que, por serem já moldadas em xisto, atestam a importância da movimentação tectónica para o soerguimento das Serras de Xisto. Esta crista permite ainda ressaltar a importância da rejeição da falha de Cebola, que limita o graben a Norte, interrompendo aí a continuidade deste afloramento quartzítico e que, na crista principal, está bem patente no acentuado desnível existente entre as serras do Batouco, a Norte da falha de Cebola, e a do Vidual, localizada a Sul dessa falha. Pela sua reduzida dimensão, mas também pela clareza e expressão das formas, surge como um excelente exemplo da movimentação tectónica, por ser facilmente observável no campo, sendo por isso muito útil em termos didáticos.

Prosseguindo a análise, chegamos ao sector mais setentrional da crista, onde esta alcança a sua maior altitude (1107 e $1106 \mathrm{~m}$, nos pontos culminantes da serra do Batouco). Mais para NW, os quartzitos desaparecem, exceto no pequeno afloramento dos Penedos de Fajāo, onde também num pequeno graben se conserva uma dobra sinclinal deitada, que sofreu uma ligeira rotação relativamente à direção geral do afloramento, e em cuja falha setentrional se instalou o rio Ceira, cavando um vale muito profundo, em forma de V. 


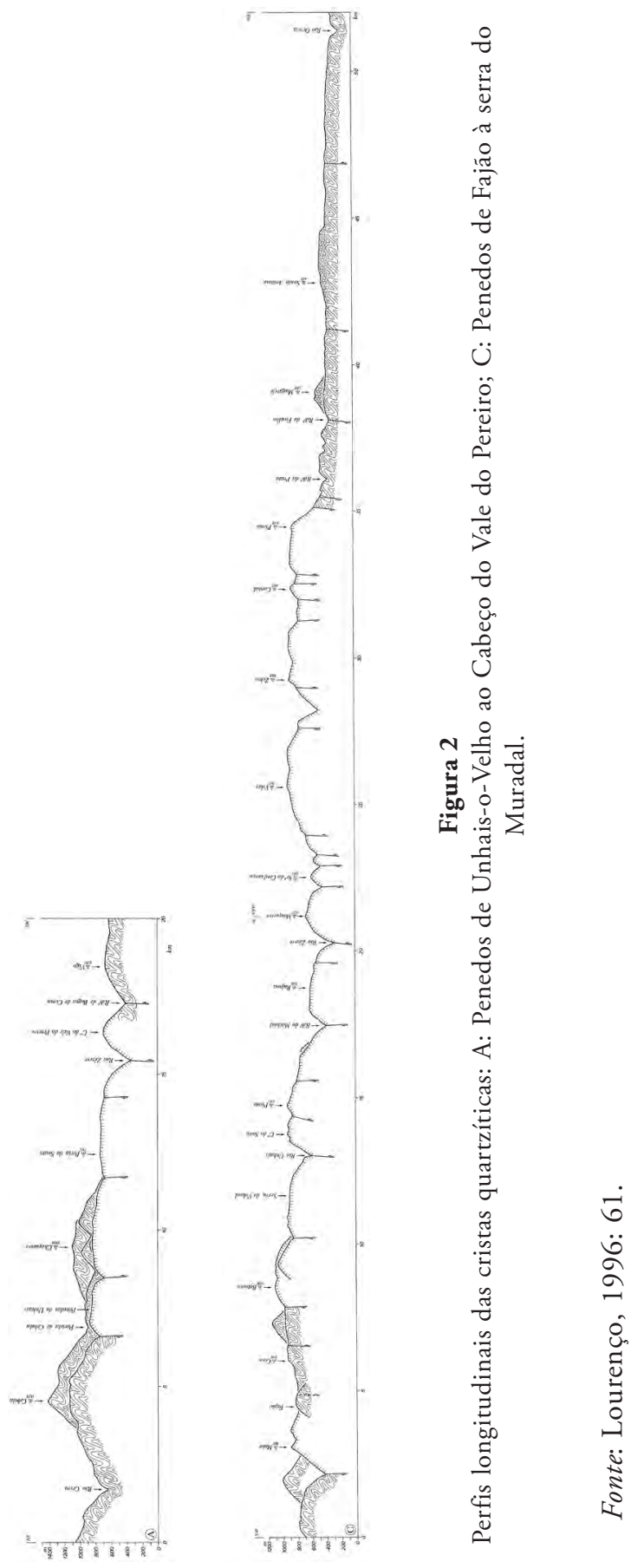




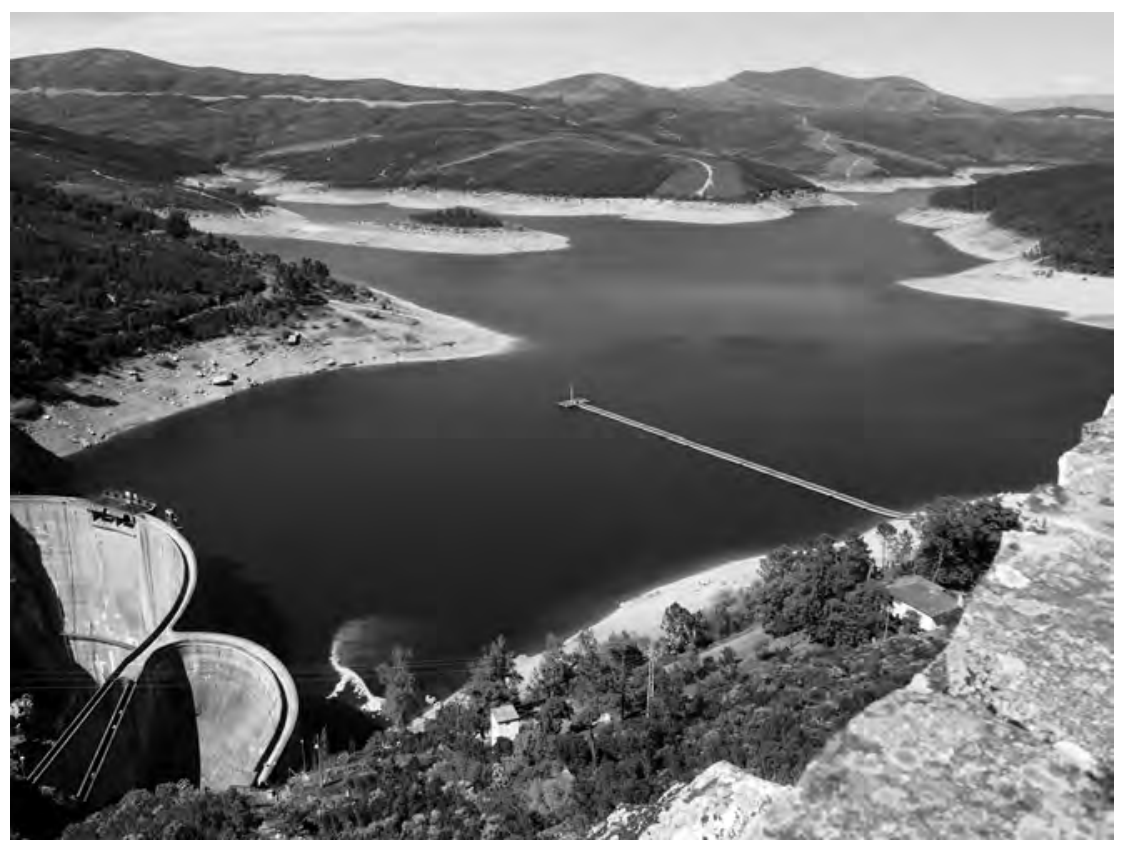

\section{Fotografia 2}

Vista geral da albufeira criada pela barragem de Santa Luzia, situada no canto inferior esquerdo.

Fotografia de L. Lourenço, tomada a 26 de agosto de 2015.

\section{Os meandros do médio Zêzere}

Numa primeira observação, como referiu O. Ribeiro (1949, p. 80), são as cristas quartzíticas que separam dois tipos de paisagem diferentes, consoante se situem a montante ou a jusante delas. Por outro lado, se em ambas as situações é possível encontrar meandros ativos, só a montante delas se encontram conservados antigos meandros que foram abandonados. 


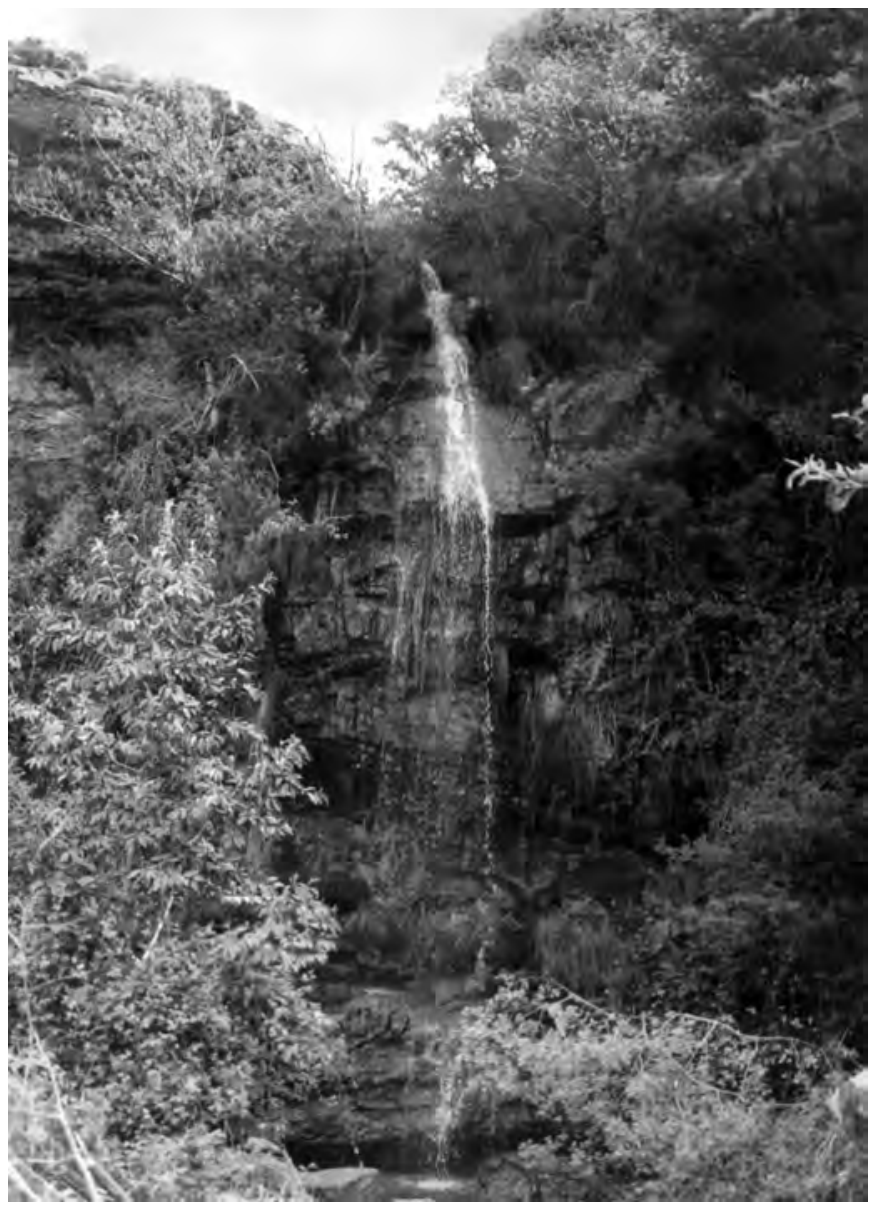

Fotografia 3

Aspeto da bela queda de "Água de Alta", situada a Sul do Orvalho, com cerca de $25 \mathrm{~m}$ de altura.

Fonte: Lourenço, 1996: 155.

\section{Meandros ativos}

Todavia, numa observação mais atenta, vai ser o acidente tectónico da Abitureira a marcar essa diferença, uma vez que, a jusante dele, os meandros 
são profundamente encaixados, "de trincheira", com vertentes simétricas e abruptas, constituídos por sinuosidades de traçado rígido (Figura 3), enquanto que, para montante daquele acidente, se desenvolvem meandros "de dureza", fortemente dissimétricos (Figura 4), com uma evolução rápida, que deixou numerosos braços abandonados (Daveau, 1985: 232), por corte dos pedúnculos dos respetivos meandros.

Como, em geral, a rede hidrográfica se encontra muito adaptada à apertada malha de fraturas, o rio Zêzere organizou-se, preferencialmente, através de curtos tramos retilíneos, explorando a malha de fraturas que, infletindo bruscamente de direção, obrigam o rio a meandrizar (Figura 3). Por sua vez, essa rede de fraturas fragilizou ainda mais o xisto, favorecendo o progressivo entalhe do rio, que, assim, se encaixou profundamente.

Ainda que não se tenham encontrado depósitos de terraço ao longo deste setor, uma série de rechãs deixa adivinhar uma vale mais alto, que terá sido fossilizado pelo coluvião vermelho, que mencionaremos adiante, sobre o qual, antes do encaixe atual, se terá reorganizado uma drenagem meandrizante que, à medida que foi evacuando os materiais constituintes do coluviáo, foi de encontro ao substrato rochoso, tendo-se ajustado às fraturas nele existentes, as quais terão imprimido um carácter mais rígido aos meandros do vale anterior e que terão servido de base à instalaçấo dos atuais.

Deste modo, quer a tipologia, quer a evoluçáo dos meandros, parecem assentar essencialmente em critérios tectónicos. Pela geometria das suas formas caprichosas, merecem referência os magníficos meandros ativos que se desenvolvem a montante do acidente da Abitureira, designadamente o dos Caneiros, que contorna o Cabeço da Marinheira, imediatamente a montante do acidente e a jusante das Cambas, seguindo-se os de: Ademoço, Janeiro de Cima, que de entre todos é o mais espetacular (Fotografias 4 e 5), Carregal-Dornelas-Barroca e, por último, o que se desenvolve a montante do Cabeço do Pião até Ourondo-Silvares (Figura 4). 


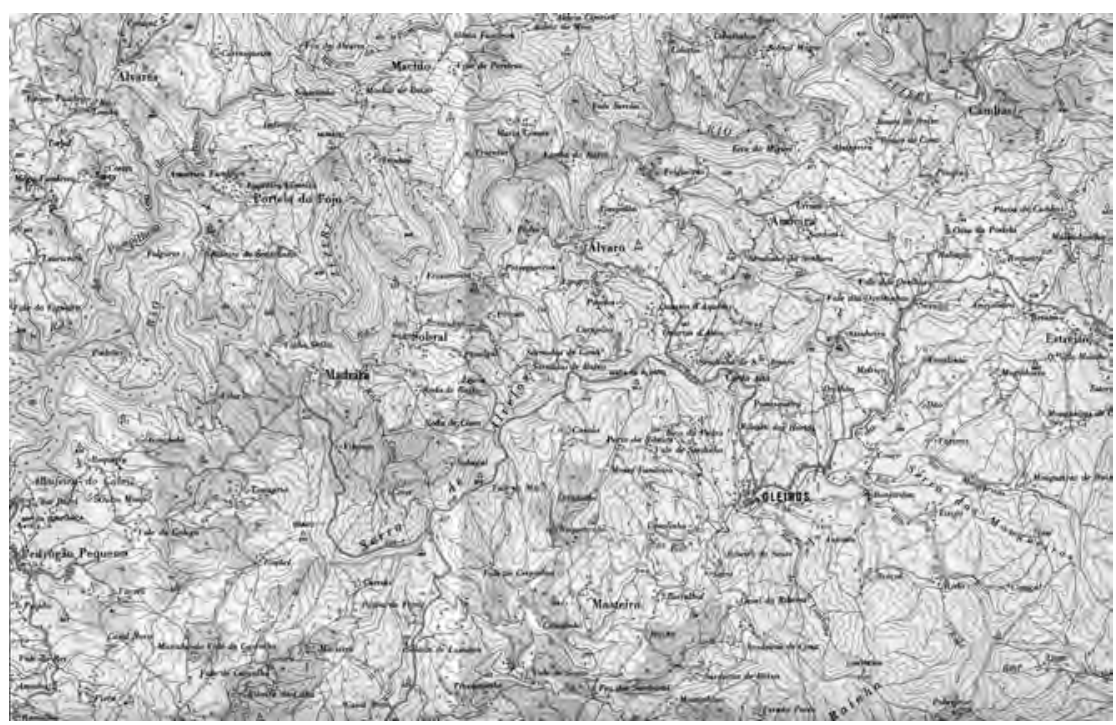

\section{Figura 3}

Sequência de meandros "de trincheira" do rio Zêzere, entre a confluência do rio Unhais e a falha da Abitureira, realçados pela albufeira da barragem do Cabril.

Fonte: Carta de Portugal, 1/100 000, Folha 24.

\section{Meandros abandonados}

Em alguns dos atuais meandros ativos, como é o caso de Janeiro de Cima ou da Barroca, é possível observar os antigos pedúnculos de meandro que, ao terem sido cortados naturalmente, nos designados cut-off, deixaram abandonados antigos braços do meandro, cuja forma geralmente ainda se encontra bem conservada, permitindo a sua fácil identificação (Fotografias 5 e 6). 


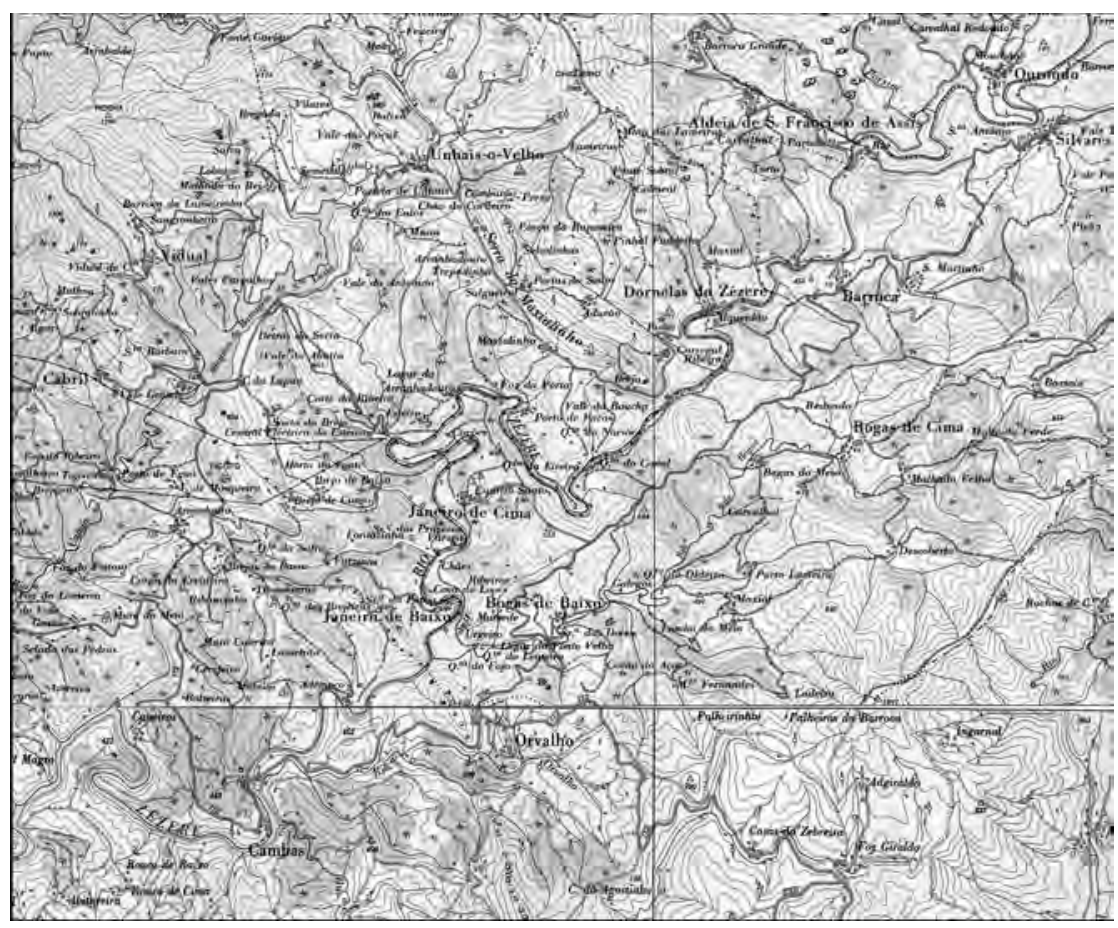

Figura 4

Caprichosos meandros ativos, "de dureza", do rio Zêzere, a montante da falha da Abitureira.

Fonte: Carta de Portugal, 1/100 000, Folhas 20 e 24.

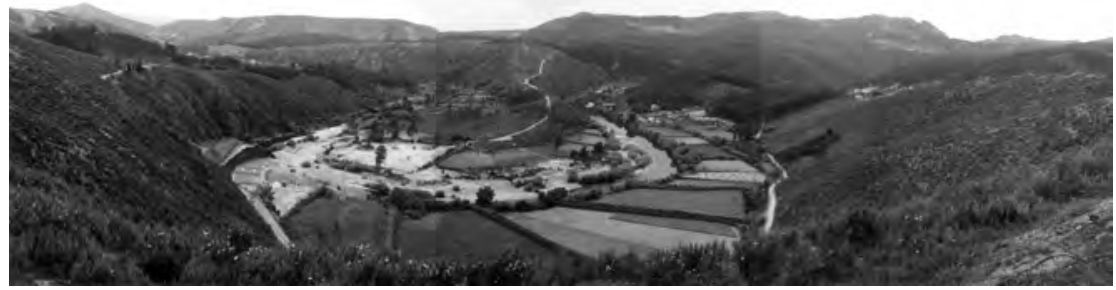

Fotografia 4

Aspeto geral do meandro situado imediatamente a montante de Janeiro de Cima, visto de NE, também representado na fotografia seguinte. Além da beleza do lacete, identifica-se o leito maior, quase completamente preenchido por campos agrícolas, exceto na margem convexa, onde a natural deposição de materiais deu origem a uma intensa exploração de areias.

Fonte: Lourenço, 1996: 150-151. 


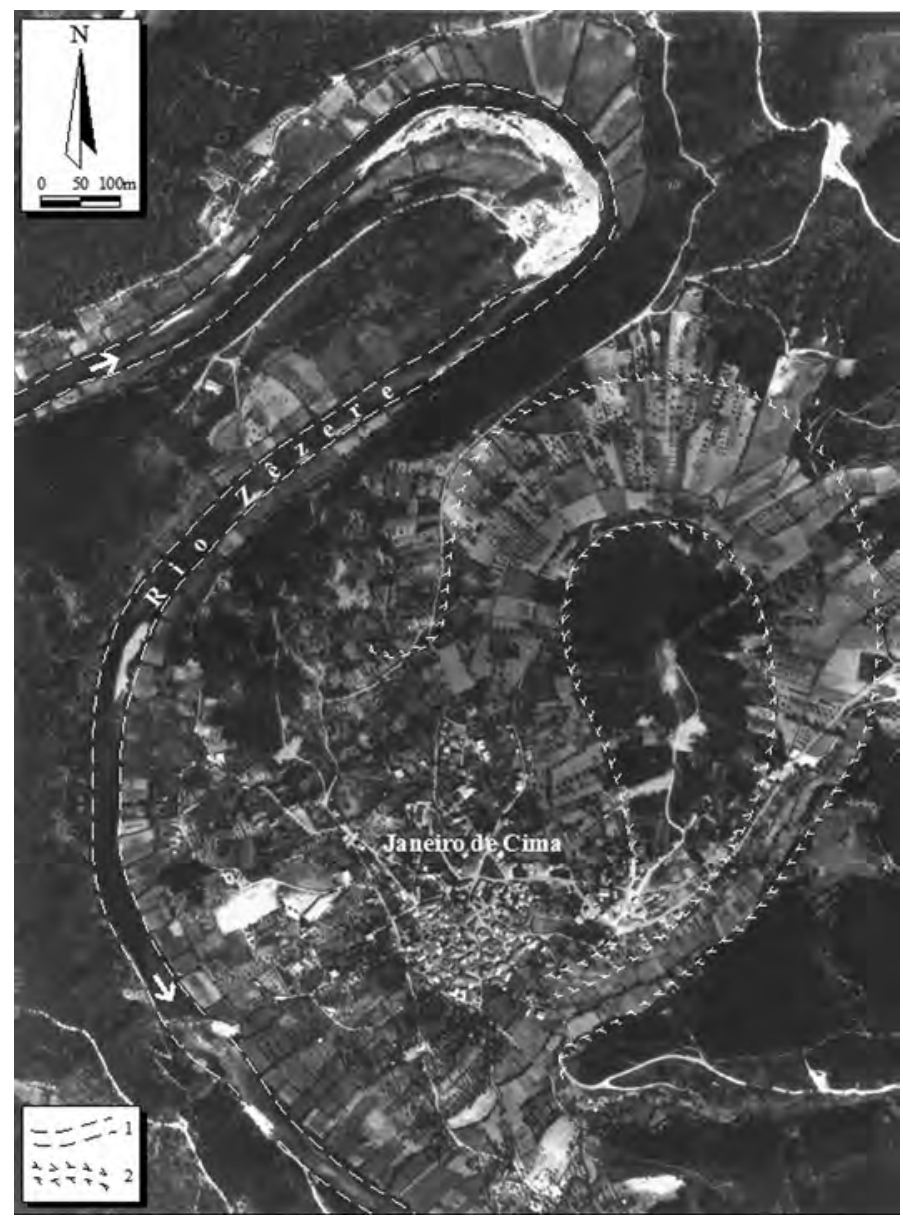

\section{Fotografia 5}

Vista aérea do meandro abandonado de Janeiro de Cima, o maior das Serras de Xisto. 1 - Leito ordinário do rio Zêzere; 2 - Limites do antigo meandro.

Fonte: Lourenço, 1996: 148.

Estes meandros abandonados merecem referência por outras razóes, designadamente em termos de aproveitamento agrícola, ao permitirem superfícies aráveis relativamente extensas, em vertentes onde escasseiam áreas aplanadas e, por conseguinte, serviram para a implantação de aldeias. Mas, do ponto de vista 
geomorfológico, interessam sobretudo porque, durante a fase de reorganização e encaixe da drenagem, eles foram poupados à erosão fluvial, permitindo a conservação de depósitos de cobertura, em particular do coluvião antes referido, que se revelam preciosos auxiliares para descodificar a evolução morfogenética do vale do rio Zêzere.

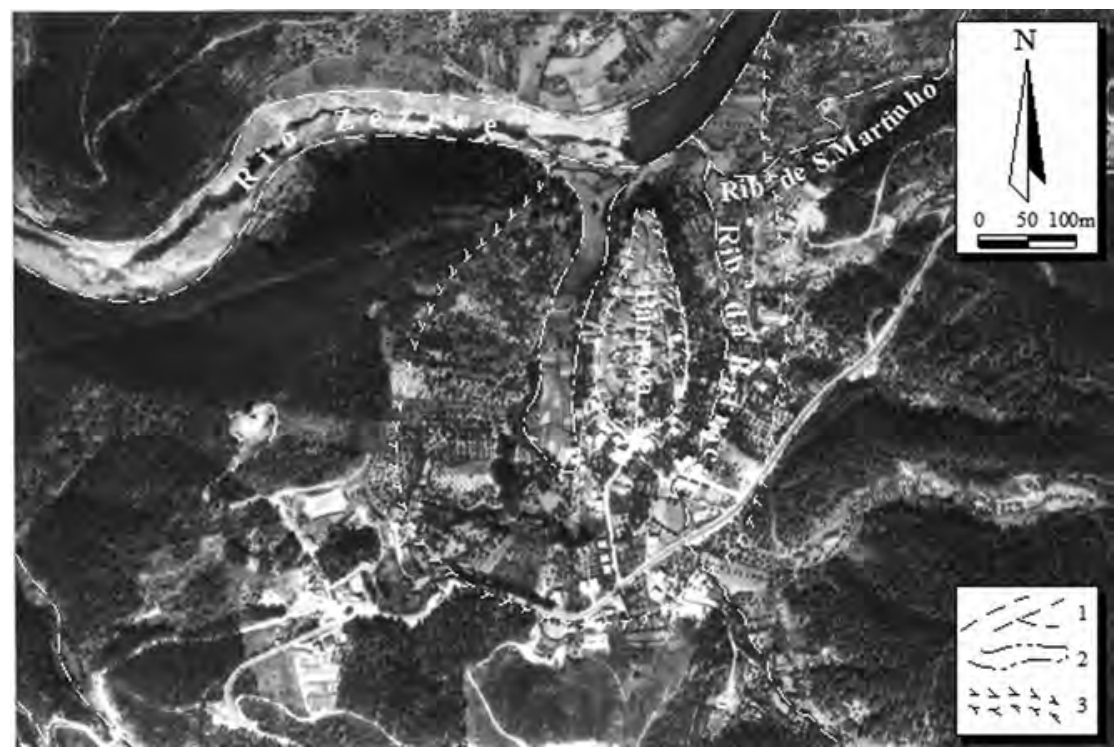

\section{Fotografia 6}

Vista aérea do meandro abandonado da Barroca, rio Zêzere, onde se destaca uma antiga frente de exploração dos depósitos de vertente que o preenchem. 1 - Cursos de água; 2 - Frente de exploraçáo; 3 - Antigo meandro.

Fonte: Lourenço, 1996: 144.

Depósitos de vertente, essencialmente xistosos

Os depósitos de vertente de origem xistosa mais frequentes no vale do rio Zêzere são de dois tipos. Um deles é essencialmente argilo-conglomerático, heterométrico, enquanto o outro apresenta carácter conglomerático, 
monotípico, com tendência mais homométrica. De seguida, passaremos a designá-los, genérica e respetivamente, por depósitos vermelhos e depósitos de patelas.

De facto, a cor é o elemento que, à primeira vista, permite estabelecer desde logo a distinção mais fácil entre estes dois grandes tipos de depósitos, os de matriz predominantemente areno-argilosa (vermelhos) e os essencialmente cascalhentos (de patelas), observados um pouco por toda a área estudada.

\section{Depósitos vermelhos}

Macroscópica e genericamente podemos caracterizá-los por se apresentarem heterométricos, argilo-conglomeráticos, imaturos, de tonalidade vermelho-acastanhada, com calhaus de xisto, quartzo e, por vezes, de quartzito, normalmente angulosos a sub-angulosos e com abundante matriz, a qual raramente é inferior a $30 \%$ e muitas vezes chega a ser superior a $70 \%$ da massa total.

Como veremos, por baixo do depósito vermelho aparecem, também, com frequência depósitos de patelas semelhantes aos que serão analisados com mais pormenor no ponto seguinte.

Todavia, as suas características macroscópicas, bem como a percentagem de matriz argilosa e o grau de compacidade, são normalmente diferentes das daqueles. No entanto, quando presente, o depósito de patelas subjacente ao depósito vermelho aparece sempre associado a este, pelo que serão descritos em conjunto.

A distribuição geográfica dos depósitos vermelhos localiza-se, preferencialmente, a cotas baixas, ou seja, a altitudes inferiores a 400/450 metros, embora, excecionalmente, nesta bacia hidrográfica do rio Zêzere, possa alcançar $650 / 700 \mathrm{~m}$.

Além disso, os depósitos desenvolvem-se sobre superfícies aplanadas, normalmente associadas a rechãs e a terraços fluviais. Por vezes, preenchem antigos barrancos ou entulham meandros abandonados, encontrando-se sempre em situação de abrigo, pelo menos relativo. 


\section{Depósitos do Fosso do Zêzere}

Os depósitos vermelhos do Fosso do Zêzere assumem particular importância a montante das cristas quartzíticas do médio Zêzere, nas imediaçôes de Janeiro de Baixo, Janeiro de Cima, Barroca e nas partes vestibulares das ribeiras do Paúl e de Ximassa.

A jusante das cristas são raros e, na generalidade, encontram-se submersos pelas águas da albufeira da barragem do Cabril, só sendo visíveis em anos muito secos, como acontece com o depósito localizado junto da antiga aldeia do Vilar, que foi submergida pelas águas da albufeira.

Neste caso, trata-se de um conglomerado heterométrico, com aspeto caótico, sem uma definição preferencial de leitos, dando-lhe um carácter fanglomerático, com uma espessura aparente superior a $25 \mathrm{~m}$ e tonalidade vermelha, muito viva. Os calhaus de xisto partem-se com muita facilidade pois, embora mantenham a sua forma exterior, internamente apresentam um elevado grau de alteração que quase os transforma em argila. Esta alteração será sem dúvida posterior à deposição e poderá, eventualmente, ter sido acelerada pelos longos períodos de submersão a que o depósito passou a estar sujeito depois de Fevereiro de 1954, altura em que a barragem do Cabril entrou em carga.

Contudo, não só porque estes depósitos se desenvolvem a cotas superiores às normais para este tipo de depósitos, mas também porque alguns deles permitem estabelecer a transição para o depósito de patelas, há situações que mereceram uma referência e que apresentamos a seguir

\section{Depósitos de Unhais-o-Velho e da Pampilhosa da Serra}

A montante da crista quartzítica dos "Penedos de Unhais", a uma altitude que ronda 700 metros, encontram-se depósitos vermelhos, só possíveis de se manterem a esta altitude em função da situação de abrigo que a crista lhes proporciona, uma vez que dificulta o encaixe da ribeira. 
Ainda na ribeira de Unhais, mais a jusante, em função de antigas meandrizaçóes do rio e do alargamento local do vale por elas proporcionado, conservam-se já à cota normal, pelos 400 metros de altitude, como sucede no depósito vermelho localizado na barreira da estrada do entroncamento de acesso ao Hospital de Pampilhosa da Serra com a EN 112, junto ao km 24.

Trata-se de um conglomerado de xisto, muito compacto, com tendência homométrica e que parece ter sofrido uma grande alteração após a deposição, traduzida na acentuada argilização das patelas de xisto, fazendo lembrar a já descrita para o depósito do Vilar. De onde em onde, disseminados na matriz, observam-se calhaus de grande dimensão, os quais na base chegam a atingir $25 \mathrm{~cm}$, mas o seu tamanho vai diminuindo progressivamente para o topo.

\section{Depósitos do Sobral do Gaviáo e da Selada Cova}

Estes depósitos situam-se quase no topo do Alto da Cabeça Gorda, por volta de 600 metros de altitude, tendo-se conservado a expensas de uma extensa rechã, situada pelos 540-550 metros.

Localizam-se, respetivamente, pelos kms 33,3 e 34,3 da Estrada Nacional 112, que liga a Portela do Vento a Castelo Branco.

O que resta do depósito do Sobral do Gavião fossiliza um barranco e serve para demonstrar que o depósito seria bem mais desenvolvido do que hoje se apresenta.

O da Selada Cova, muito mais extenso (Fotografia 7), quase foi destruído, como aliás é frequente suceder aos depósitos situados junto a estradas, utilizados para tapar buracos e regularizar as bermas das estradas de macadame e de terra batida. No entanto, neste caso, a remoçáo do material do depósito teve a vantagem de deixar a descoberto grande parte de uma paleotopografia ravinante no xisto, sobre a qual o depósito se instalou e que permitiu fazer observaçôes que de outro modo teria sido impossível realizar.

Acresce ainda que, tanto no Sobral do Gavião, como na Selada Cova, o depósito vermelho está sobreposto por depósito de patelas, o que nos leva a 
concluir - se este depósito vermelho corresponder aos que temos vindo a descrever - terem existido pelo menos dois períodos favoráveis à formaçáo de depósitos de patelas, um anterior e outro posterior à deposição do material vermelho.

Porque pensamos que melhor do que descrever muitos depósitos será preferível analisar detalhadamente alguns deles, o depósito da Selada Cova mereceu-nos particular atençáo, na medida em que, sendo espesso e complexo, poderá encerrar elementos fundamentais para a justificação da evolução do relevo nas Serras de Xisto.

Com efeito, a base do depósito é constituída por um argilito esbranquiçado com laivos amarelados que preenche uma paleotopografia ravinante (A). Sobre o xisto, foram observados localmente restos de crosta férrica. Estes elementos, associados à caulinite detetada nas amostras, embora pouco abundante e em mau estado de conservação, levaram-nos a pensar que o argilito se terá formado numa fase climática marcadamente hidrolisante.

Sobre o argilito ter-se-ão desenvolvido duas fases de deposiçấo de materiais de cor vermelha $-\mathrm{B}_{1}$ e $\mathrm{B}_{2}-$ de argilo-conglomerado de xisto, imaturo, com os calhaus de maior dimensáo a situarem-se pelos 5 a $8 \mathrm{~cm}$ e com matriz normalmente compreendida entre 20 e $40 \%$.

A fase $B_{2}$ foi, em grande parte, destruída por um largo barranco que também afetou o topo de $B_{1}$ e que assinala uma marcada descontinuidade com o depósito de patelas que, posteriormente, o preencheu e no qual também é possível distinguir muito claramente duas fases $-\mathrm{C}_{1}$ e $\mathrm{C}_{2}-$ que analisaremos com mais pormenor ao tratar dos depósitos de patelas.

\section{Depósitos curvifluxivos formados por leitos alternantes de patelas com material fino}

Este tipo de depósito distingue-se bem do anterior porque a alternância entre leitos mais finos e mais grosseiros é muito nítida. Com efeito, os leitos grosseiros são constituídos por patelas de xisto, normalmente de tendência homométrica, mas por vezes a incluírem calhaus de maior dimensão, cons- 
tituídos por xisto, grauvaque e quartzo, enquanto os leitos mais finos são predominante arcósico-argilosos, embora possam conter pequenas patelas de xisto.
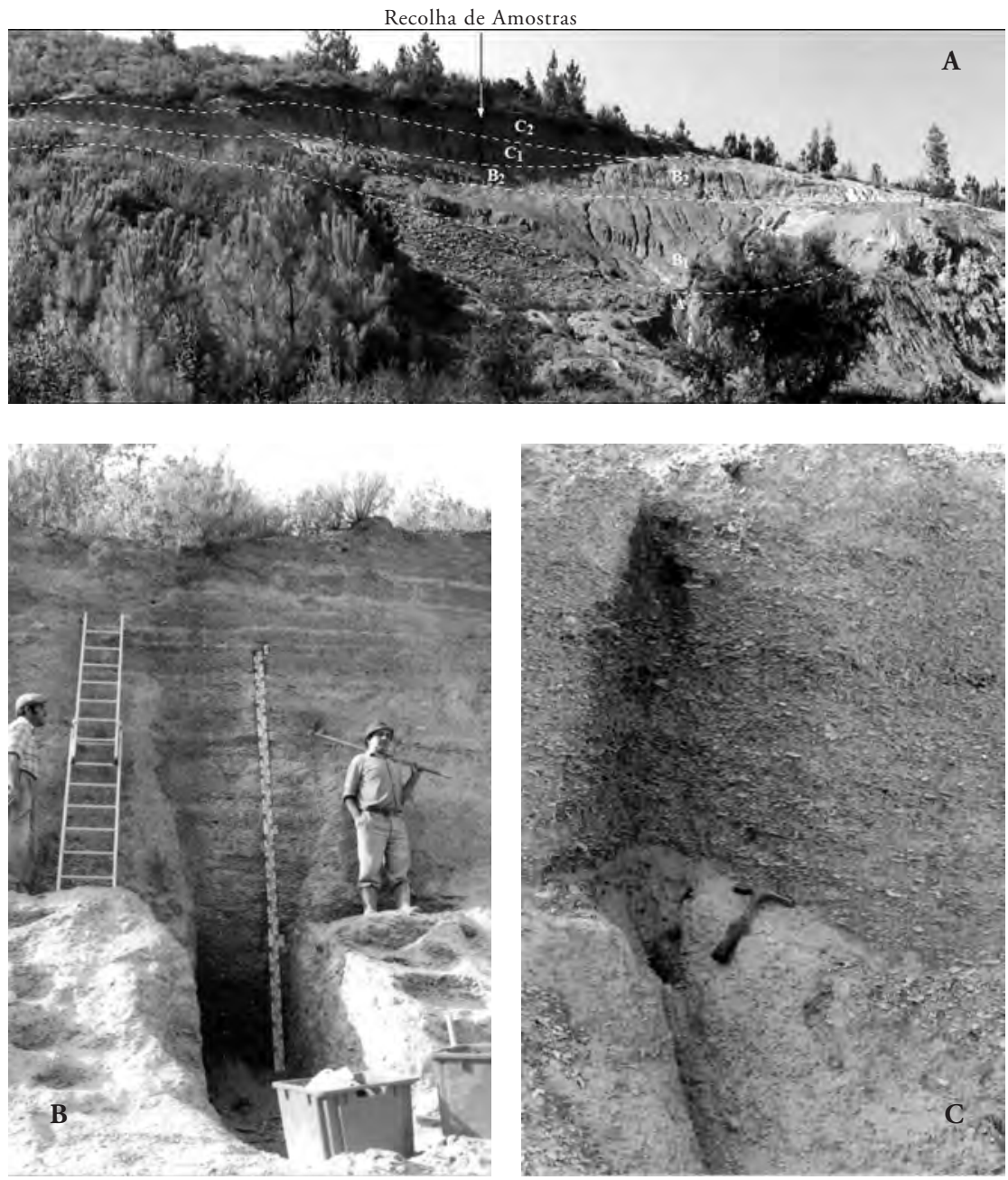

Fotografia 7

Depósito da Selada Cova: A - Vista geral ( $\mathrm{A}$ a $\mathrm{C}_{2}$, ver descrição no texto); $\mathrm{B}$ - Pormenor do corte assinalado em A, durante a sequência de recolha das amostras; $\mathrm{C}$ - Detalhe da transiçấo entre $\mathrm{B}_{2}$ e $\mathrm{C}_{1}$.

Fonte: Lourenço, 1996: 220-221. 
Esta alternância de níveis mais cascalhentos com níveis mais argilosos dever-se-á, provavelmente, às condiçóes de deposição, por sua vez dependentes de variaçóes significativas na quantidade, espessura e periodicidade da neve e dos períodos de gelo/degelo. No entanto, é difícil tentar estabelecer uma relação direta entre as características do depósito e as condiçóes ambientais no momento da deposição.

Por outro lado, normalmente, a estratificação não é tão regular como no tipo anterior, pois, muitas vezes, ao longo de um mesmo leito, individualizam-se bolsadas mais espessas ou surgem estiramentos que o adelgaçam, conferindo-lhe um certo grau de irregularidade.

Com efeito, esta particularidade, que se observa muito bem neste tipo de depósitos, é mais difícil de encontrar nos do tipo anterior. Deve-se à existência de estruturas arqueadas (curvifluxóes), quer em grande, afetando a generalidade do leito, quer no pormenor, dando-lhe pequenos retoques, as quais serão de atribuir à água que pode circular e congelar no interior do depósito.

Deste modo, nas zonas de fluência da água, ou seja, nos lóbulos mais cascalhentos onde predominam as patelas de xisto, quando congela, a água aumenta de volume e, como consequência, incha a estrutura, levando à formação de involuçôes em roseta no seu interior, ao mesmo tempo que conduz ao arqueamento dos níveis superiores, mais finos.

A congelação da água no interior do depósito, embora seja um fenómeno raro na atualidade, ainda pode ser observada em situaçóes de maior altitude, quando se verifica a permanência por alguns dias consecutivos de determinados tipos de tempo.

Os depósitos curvifluxivos localizam-se, de modo geral, acima de 750/800 metros. Esta é, pois, outra particularidade que os distingue dos depósitos de patelas antes descritos, os quais podem ser encontrados também a baixas altitudes.

De entre os depósitos curvifluxivos indicamos alguns dos que podem ser observados mais facilmente e que, pelas suas características, constituem bons exemplos deste tipo de depósitos.

Voltado a Nascente, referimos um depósito situado pelos 880 metros de altitude, numa barreira da estrada da Catraia do Rolão para Fajão, 500 metros a 

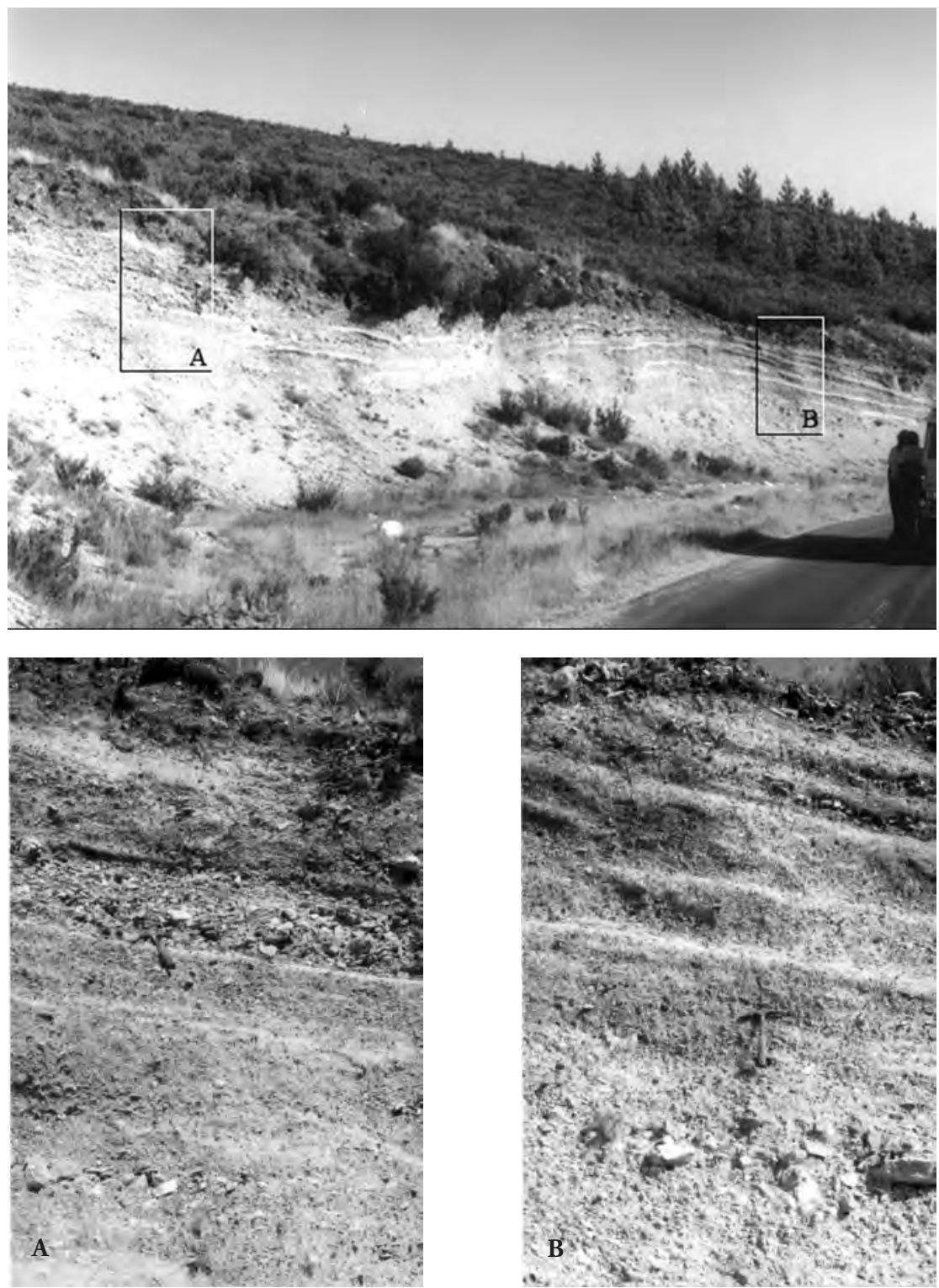

\section{Fotografia 8}

Em cima, aspeto do depósito curvifluxivo situado entre a Selada da Cova e a Selada das Porcas (Talude da Estrada Catraia do Rolão-Fajão). Em baixo, à esquerda, pormenor de bolsada cascalhenta e, à direita, detalhe da alternância de sucessivos leitos de material mais fino e mais grosseiro, com material bastante mais grosseiro na base.

Fonte: Lourenço, 1996: 238-239. 
Sul da Selada da Cova (Fotografia 8), onde também é muito nítida a alternância dos leitos grosseiros com leitos finos, bem como o arqueamento destes últimos, por vezes, em função de bolsadas de material mais grosseiro, com abundantes clastos angulosos e sub-angulosos de quartzo e xisto.

Um outro, também facilmente acessível, fossilizou a caixa de falha de Cebola, nas cabeceiras da ribeira, em parte ainda conservado (Fotografia 9), apresenta caraterísticas semelhantes ao anteriormente descrito.

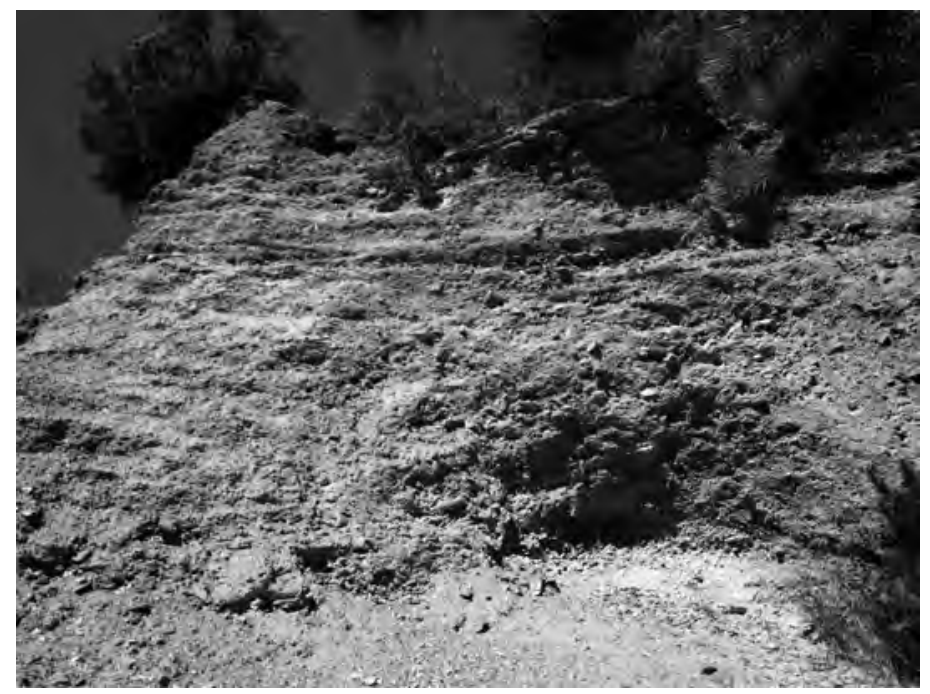

Fotografia 9

Vista do que resta do depósito periglaciar que fossilizou a caixa da falha de Cebola, apresentada na Fotografia 1.

Fotografia de L. Lourenço, tomada a 27 de maio de 2015).

Os dois subtipos principais de depósitos de patelas em função das caraterísticas dominantes em cada um deles e que, naturalmente, estiveram dependentes das respetivas condiçóes de formação, permitem estabelecer o seu respetivo posicionamento no tempo.

É evidente que, para além destes dois subtipos mais "puros", existem algumas situaçóes intermédias, de mais difícil classificação, na medida em que podem refletir condiçôes muito localizadas, quer do ponto de vista climático, 
quer de natureza litológica, ou ainda poderão resultar da retoma de material de depósitos de gerações anteriores.

No entanto, com base na tipologia apresentada, o depósito do primeiro tipo (sequências $\mathrm{C}_{1}$ e $\mathrm{C}_{2}$, da Fotografia 7 ) será o mais antigo, tendo-se formado num clima frio relativamente seco, provavelmente do Pleniglaciar superior (Würm III), até porque assenta sobre o depósito vermelho atrás referido.

O segundo tipo, curvifluxivo, constituído por leitos de patelas alternantes com material mais fino (Fotografia 8), será mais recente, correspondendo a um clima também frio, mas, provavelmente, mais húmido do que o anterior, podendo corresponder ao final do Pleniglaciar superior (Würm III) ou já mesmo ao Tardiglaciar antigo.

Estes depósitos poderão, eventualmente, ser correlacionáveis com os da Zouparria do Campo, situados no Baixo Mondego, também "susceptíveis de subdivisão em duas subunidades de igual representatividade" (Soares et al., 1985, p. 91-92) e considerados "essencialmente würmianos, ou mesmo holocénicos" (Soares et al.,1993: 811-2).

Ora, como nas áreas de maior altitude se terão desenvolvido processos nitidamente periglaciares, seria de esperar o aparecimento, nas áreas aplanadas, das formas correspondentes a esses processos, tais como turfeiras, "pieds de vache", círculos de pedras e outros, o que não se observou. No entanto, alguns vestígios encontrados em situações muito pontuais e localizadas, obrigam-nos a admitir tal hipótese como provável.

Deste modo, na área aplanada da parte oriental da Serra do Chiqueiro (1060 m) observámos situaçóes de pormenor, muito incipientes e localizadas, que nos levaram a admitir a possibilidade de terem existido turfeiras (Fotografia 10). De facto, algumas das situaçóes que a toponímia local refere como "Relva", "Relvão" ou "Relvoeiro", associadas à existência de relva nalgumas áreas aplanadas, em particular nos colos, poderão constituir um vestígio que testemunha a existência de algumas dessas condiçóes.

Contudo, o remeximento do solo, através de sucessivas mobilizaçôes superficiais, e, por vezes, até da própria rocha, primeiro para sementeira de 
penisco e, depois, para plantação de árvores, não só destruíram os "Relvôes" e as eventuais formas periglaciares existentes à superfície, mas também alteraram as condiçóes de drenagem que as mantinham, levando a que, atualmente, estas áreas estejam ocupadas por mato.

No entanto, junto à Selada de Belide, num corte duma barreira da estrada, foi possível observar sobre o xisto um pelito argiloso de tonalidade amarelada, onde se notam pequenos calhaus de xisto, que parecem dispostos segundo os mesmos alinhamentos da rocha mãe, o que nos leva a admitir uma alteração da rocha "in situ".

Ora, sobre este pelito assenta um solo heterométrico, grosseiro, com abundante matriz de cor escura, negra, com muitos dos calhaus dispostos na vertical (Fotografia 11), que nos fazem lembrar disposições semelhantes às da formação de círculos de pedras, embora, pelas razóes antes apontadas, ou porque se encontram cobertos pelo mato, não os conseguimos encontrar.

Deste modo, na Selada de Belide, deverão ter existido formas periglaciares que na atualidade náo é possível observar. Para finalizar, no que respeita às formas topográficas, estes depósitos também fossilizam paleotopografias, pelo que tendem a adoçar as formas das vertentes, contribuindo para suavizar tanto as convexidades culminantes, as típicas formas arredondadas dos cabeços de xisto, como as concavidades basais e, ainda, para acentuar a regularidade da própria vertente, imprimindo-lhe um carácter marcadamente rectilíneo, através da fossilização dos barrancos que lhe quebravam a monotonia.

\section{Depósitos associados às cristas quartzíticas}

Os depósitos mais conhecidos, intimamente associados às cristas quartzíticas, são os de "raña", os quais alcançam particular representatividade em Espanha, mas que em Portugal também tiveram importante desenvolvimento e cujos restos ainda assumem alguma expressão nas Bacias Marginais das Serras de Xisto, tanto a NW como a SE. 


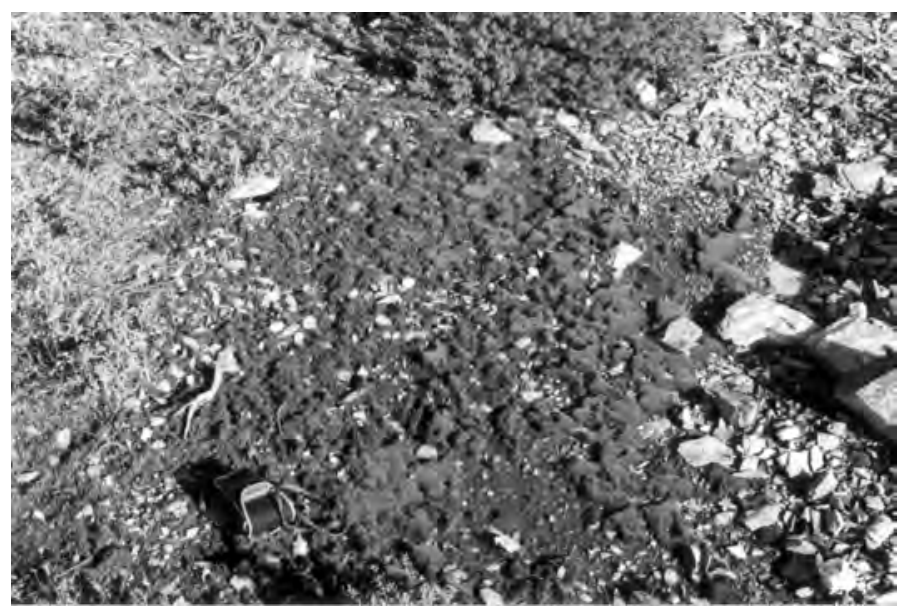

\section{Fotografia 10}

Serra do Chiqueiro. Esboço de turfeira incipiente, em formação nas atuais condiçóes climáticas.

Fonte: Lourenço, 1996: 245.

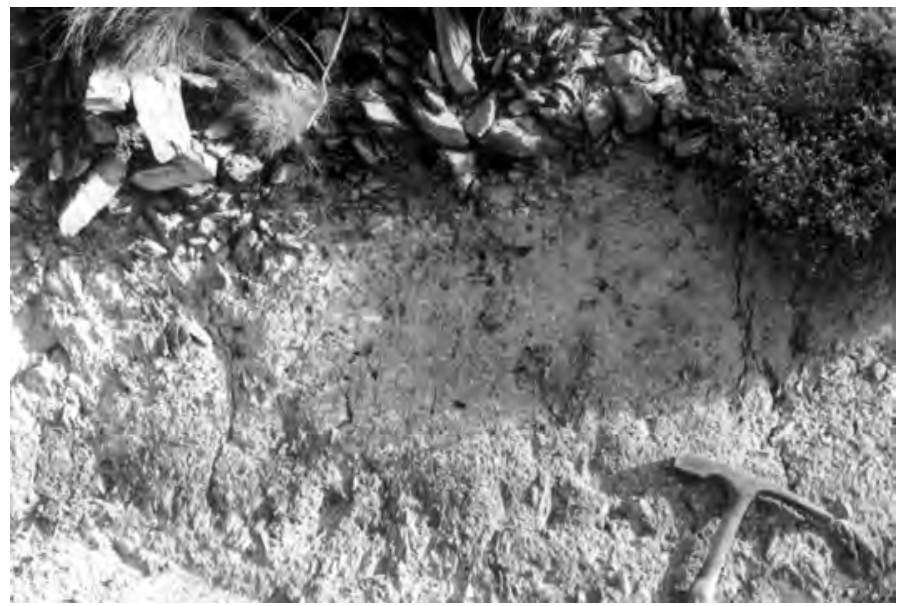

\section{Fotografia 11}

Selada de Belide. Pormenor do talude da estrada. Na base, sobre o xisto, desenvolve-se um argilito e sobre este assenta uma cobertura de calhaus grosseiros. A disposição destes calhaus deixa transparecer a existência de processos periglaciares na génese desta cobertura.

Fonte: Lourenço, 1996: 245. 
Apesar da importância e imponência de alguns alinhamentos quartzíticos que atravessam as Serras de Xisto, não deixa de ser estranho que, no interior delas, especialmente onde as cristas quartzíticas mais se salientam na morfologia, não existam importantes depósitos constituídos por material quartzítico. É evidente que, ao longo das cristas, numa distância variável entre algumas dezenas e poucas centenas de metros, se encontram depósitos cuja génese lhes está intimamente associada.

No entanto, o carácter pelicular destes depósitos não deixa de nos surpreender, em particular nas cristas situadas no fosso do Zêzere, onde deverão ter existido condiçóes de deposição semelhantes às das Áreas Marginais e no qual não se encontram formaçóes comparáveis. No entanto, porque se situam fora da área estudada não nos merecem particular destaque. Preocupar-nos-emos, então, apenas com os depósitos situados nas imediaçóes diretas das cristas, nos quais predomina uma fácies de tipo "raña”, embora não se apresentem com a característica forma de perfil trapezoidal.

Provavelmente, o facto de estas cristas serem atravessadas por rios importantes, associado ao modo como a drenagem se organiza ao longo delas, muitas vezes a desenvolver-se na base da crista, acompanhando a sua geometria, facilita a evacuação dos materiais e terá contribuído decisivamente para que no interior das Serras não se conservem depósitos muito espessos.

Por outro lado, a evolução dos quartzitos é muito lenta, pelo que é necessário que decorram longos períodos de tempo, em condiçóes climáticas de relativa aridez, para que os materiais resultantes da sua alteração não sejam evacuados para longas distâncias, condição que também não se tem verificado ultimamente, sendo, por este motivo, mais um fator concorrente para justificar a inexistência de depósitos importantes no interior das Serras.

Deste modo, o depósito heterométrico que, normalmente, ladeia as cristas ter-se-á formado noutro tipo de clima, dado que nas atuais condiçóes parece existir um défice de material no depósito, uma vez que o escoamento superficial arrasta mais material do depósito do que transporta para ele.

Além deste depósito heterométrico, de tonalidade amarelada, com variaçóes locais, existe um outro, pouco frequente, a que chamámos de- 
pósito caótico de blocos em corredor, praticamente destituído de material fino, que corresponde às escombreiras de gravidade e, ainda, um terceiro, constituído essencialmente por cascalheiras provenientes diretamente dos quartzitos.

Analisemos, pois, com mais pormenor, estes tipos de depósitos diretamente ligados às cristas quartzíticas que atravessam o vale do Zêzere.

\section{Depósitos heterométricos amarelados}

Atribuímos esta designação a um conjunto de depósitos que apresentam um carácter marcadamente heterométrico, constituídos tanto por calhaus como por blocos heterométricos de quartzito, embalados numa matriz areno-argilosa, de tonalidade amarelada, por vezes também com clastos heterométricos de xisto, muito alterados, nela disseminados.

Iniciam-se normalmente por um argilito amarelado ou esbranquiçado, o qual assenta diretamente sobre os xistos. Nestes, por vezes, observa-se uma rubefação muito nítida, tendo sido provocada provavelmente por um clima muito hidrolisante.

Em regra, estes depósitos arrancam da base dos quartzitos, com os quais contactam diretamente e, muitas vezes, prolongam-se até à base das vertentes, transmitindo-lhe uma regularidade e um carácter retilíneo impressionantes. À medida que o depósito se afasta da base da crista, a percentagem de calhaus e blocos de quartzito vai diminuindo e, em contraponto, aumenta o número dos clastos de xisto bem como a percentagem de matriz.

A extensão destes depósitos está relacionada com o volume e a altitude das cristas quartzíticas, desenvolvendo-se frequentemente para um e outro lado delas, embora se apresentem mais desenvolvidos a NE das mesmas, em direção ao eixo do sinclinal.

Este depósito que, normalmente, ladeia as cristas quartzíticas é constituído por blocos e calhaus heterométricos de quartzito disseminados numa matriz areno-argilosa. Além da sua constituição, caracteriza-se por apresentar uma 
grande regularidade na sua distribuição ao longo das cristas, assumindo sempre um carácter pelicular.

As condiçóes que terão presidido à sua formação serão análogas àquelas que foram responsáveis pela formação do topo dos depósitos de "raña”. Deste modo, ter-se-ão constituído num clima de tipo árido ou semi-árido, em que o frio e os processos de soli e gelifuxão terão desempenhado papel preponderante, podendo ter sido formados durante o Pleniglaciar médio, correspondente ao Würm II, e no Pleniglaciar superior (Würm III).

\section{Depósito caótico de blocos em corredor}

O depósito que constitui aquilo que designámos por "depósito caótico de blocos em corredor" pode ser definido como um conjunto caótico de fragmentos de quartzito, de tamanho muito diverso, sem matriz fina, com grande volume de ocos, que se dispóem desordenadamente, com os clastos de maior dimensão na parte superior do depósito.

A interpretação estereoscópica de fotografia aérea vertical bem como a observação direta no campo mostraram-nos que, a montante destes amontoados de blocos, a crista se encontra bastante fraturada e nela se desenvolvem como que passagens inclinadas, as quais ocasionam uma certa concentração de blocos a jusante das mesmas (Fotografia 12). Além disso, os blocos que preenchem os corredores seguem antigos valeiros de uma paleotopografia suave moldada nos xistos pós-Skidavianos, a qual também contribuiu para ajudar a concentrar um maior número de calhaus e de blocos de quartzito neste setor do depósito. 


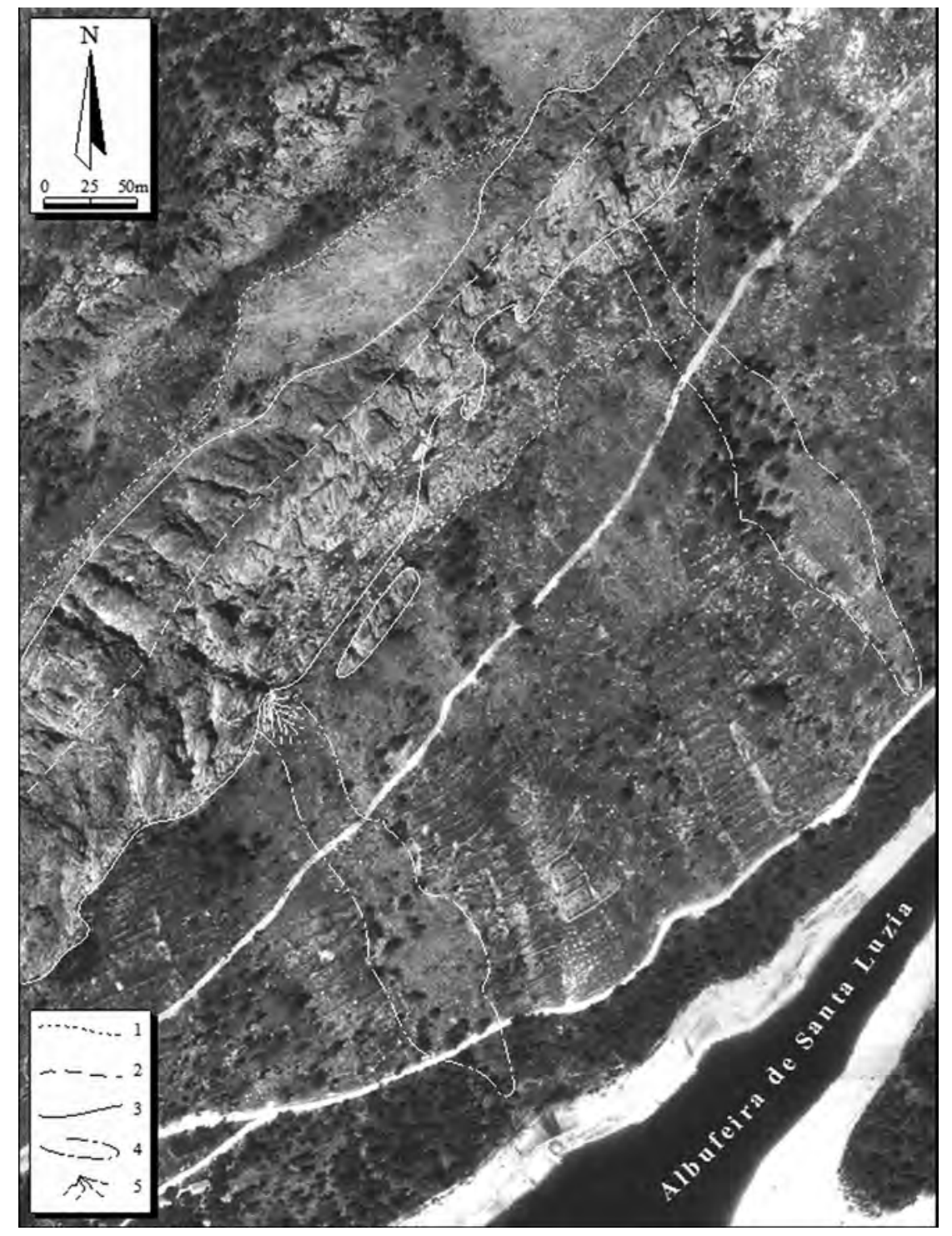

\section{Fotografia 12}

Vista aérea da Serra do Vidual, sendo visível a extensão dos dois principais depósitos caóticos de blocos em corredor. 1 - limite exterior da cobertura de calhaus; 2 - topo da crista quartzítica; 3 - base da crista; 4 - limite dos blocos em corredor; 5 - talude de gravidade.

Fonte: Lourenço, 1996: 255. 
A disposiçẫo estrutural dos quartzitos possibilita, além disso, uma maior concentraçáo do escoamento superficial, o qual terá sido responsável pelo escavamento do paleovaleiro e, depois da constituição do depósito, pela evacuaçáo de alguma matriz que se encontre disponível para ser transportada. Quanto menos matriz existir, mais dificuldade tem a vegetação para se fixar e desenvolver. Em consequência, quanto menos vegetação houver, menos entraves terá a escorrência para arrastar a matriz.

Deste modo, se nos parece simples a justificação destes aparentemente enigmáticos "depósitos caóticos de blocos em corredor", o mesmo já não sucede no que concerne à sua relaçáo com o depósito heterométrico que os ladeia. Serão contemporâneos?

A impossibilidade de se poderem observar bons cortes nestes corredores não nos permite esclarecer as nossas dúvidas. Com efeito, apenas nos taludes da estrada, bastante afastados da crista, pudemos observar o posicionamento relativo dos dois depósitos (heterométrico e blocos em corredor), os quais, contudo, nos levam a pensar que os blocos em corredor sáo posteriores ao depósito heterométrico.

Deste modo, as relaçóes com o depósito heterométrico, sobre o qual assentam ou a partir do qual evoluíram, não são muito fáceis de apurar, pelo que somos forçados a aceitar as duas como prováveis. Com efeito, tratando-se de uma evolução do depósito heterométrico, ela só poderá ser devida à evacuação do material fino. Se, porventura, forem posteriores, muito provavelmente serão contemporâneos da cobertura de calhaus que, como veremos, nos coloca o mesmo tipo de problemas de correlação, bem como das escombreiras de gravidade, que trataremos a seguir.

No que diz respeito às relaçóes dos corredores de blocos com as cristas que os alimentam verificamos que, mesmo na atualidade, na base das passagens que franqueiam a crista, existe uma concentração de calhaus, os quais formam taludes de gravidade (Fotografia 13), o que não se observa fora das passagens que exploram fraturas importantes. Deste modo, parece-nos que não só a disposição, mas até a própria existência dos blocos em corredor, estão dependentes de condições estruturais, que se situam ao nível das cristas quartzíticas. 

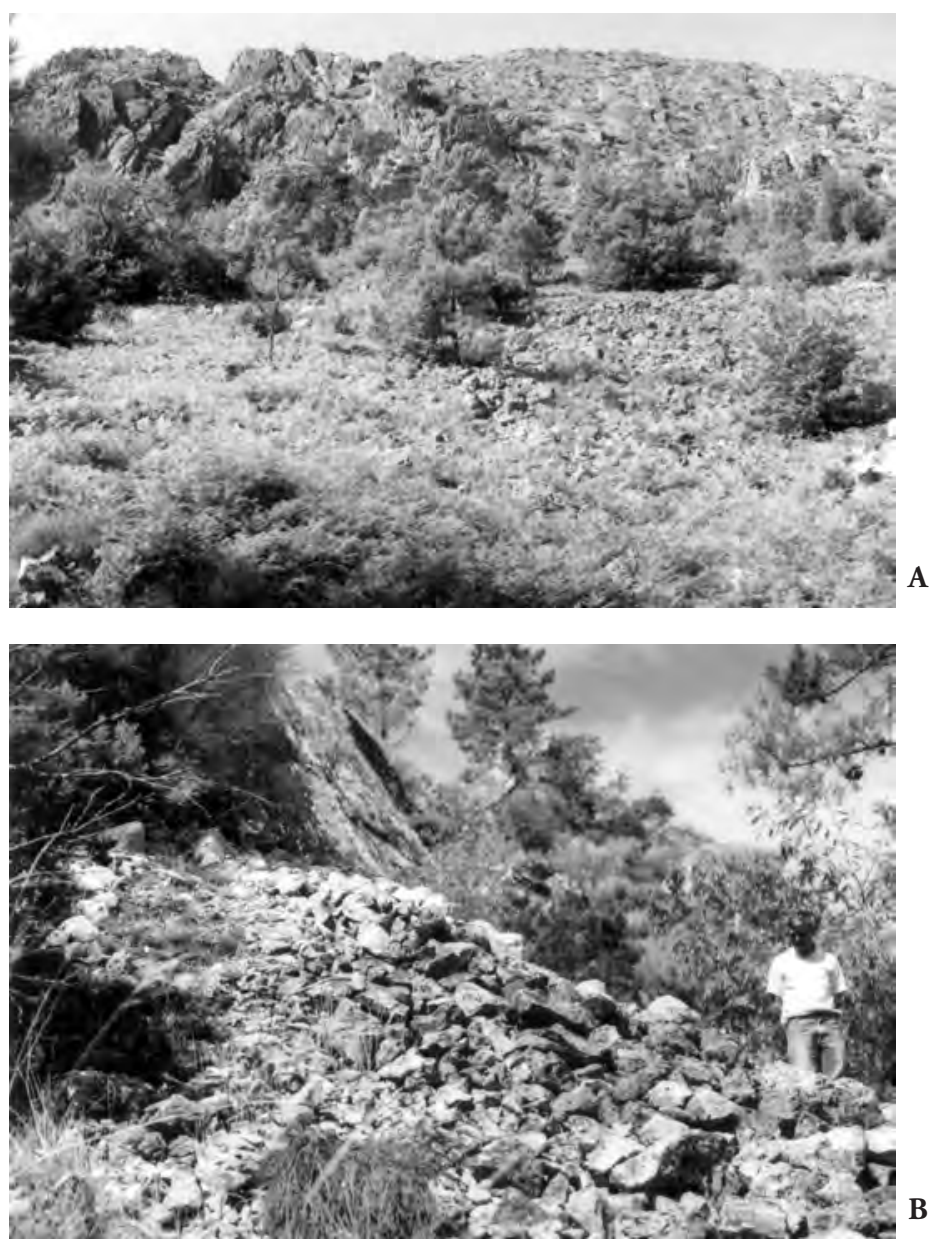

\section{Fotografia 13}

Serra do Vidual. A - Aspeto dos blocos do corredor meridional, com a crista quartzítica a barrar o horizonte; B - Pormenor do talude de gravidade, à saída da passagem da crista que se vê à esquerda, na fotografia 12 .

Fonte: Lourenço, 1996: 257.

Por fim, resta-nos ainda uma outra dúvida. Na parte superior do depósito heterométrico, nas áreas situadas mais próximo das cristas, por vezes observa-se uma cobertura de calhaus de quartzito, esparsos, assentes em matriz areno-argilosa (Fotografia 14) que também não sabemos se interpretar como 
um depósito posterior ao heterométrico ou se terá resultado da evolução deste, por lavagem da matriz fina. Contudo, em qualquer dos casos, pelo seu posicionamento, esta cobertura poderá ser de atribuir ao Tardiglaciar ou já mesmo ao Holocénico.

De facto, não só nos sentimos incapacitados para resolver esta questão, mas também não nos foi possível avaliar da importância e extensão dessa cobertura, pois apenas pode ser observada em locais sem vegetaçáo, o que só muito raramente acontece, após incêndios florestais e, quando sucede, é por períodos de tempo relativamente curtos.

\section{Escombreiras de gravidade}

As escombreiras de gravidade relacionam-se sobretudo com as cristas quartzíticas, embora também seja possível encontrá-las associadas a material xistoso. Nestas circunstâncias, quase sempre foram provocadas por ação antrópica, associada à mineração (volfrâmio) ou à extração de pedra para construção (pedreiras), pelo que não nos mereceram particular atenção.

Das associadas aos quartzitos, existem duas nas imediaçóes da barragem de Santa Luzia, que merecem ser referidas. A primeira delas situa-se logo a jusante, na margem esquerda. Julgamos que será artificial, pelo menos em parte, por incorporação de material proveniente da abertura da estrada (Fotografia 15).

A outra, aquela que assume maior significado, localiza-se a jusante do Vale Grande, entre os dois afloramentos quartzíticos que constituem a crista secundária. A sua ocorrência, nestas condiçóes, deve-se ao facto da crista ser atravessada pelo rio Unhais, o qual permite o declive suficiente, ao longo da crista, para que entre os afloramentos se possam acumular cascalheiras.

Normalmente, estas escombreiras arrancam da base da crista, assentando sobre depósito heterométrico, em condições que, à parte da dimensão dos clastos, nos fazem lembrar os "corredores de blocos" da Serra do Vidual — serão correlacionáveis? - , embora as escombreiras, porque são de gravidade, se desenvolvam sobre vertentes mais inclinadas. 


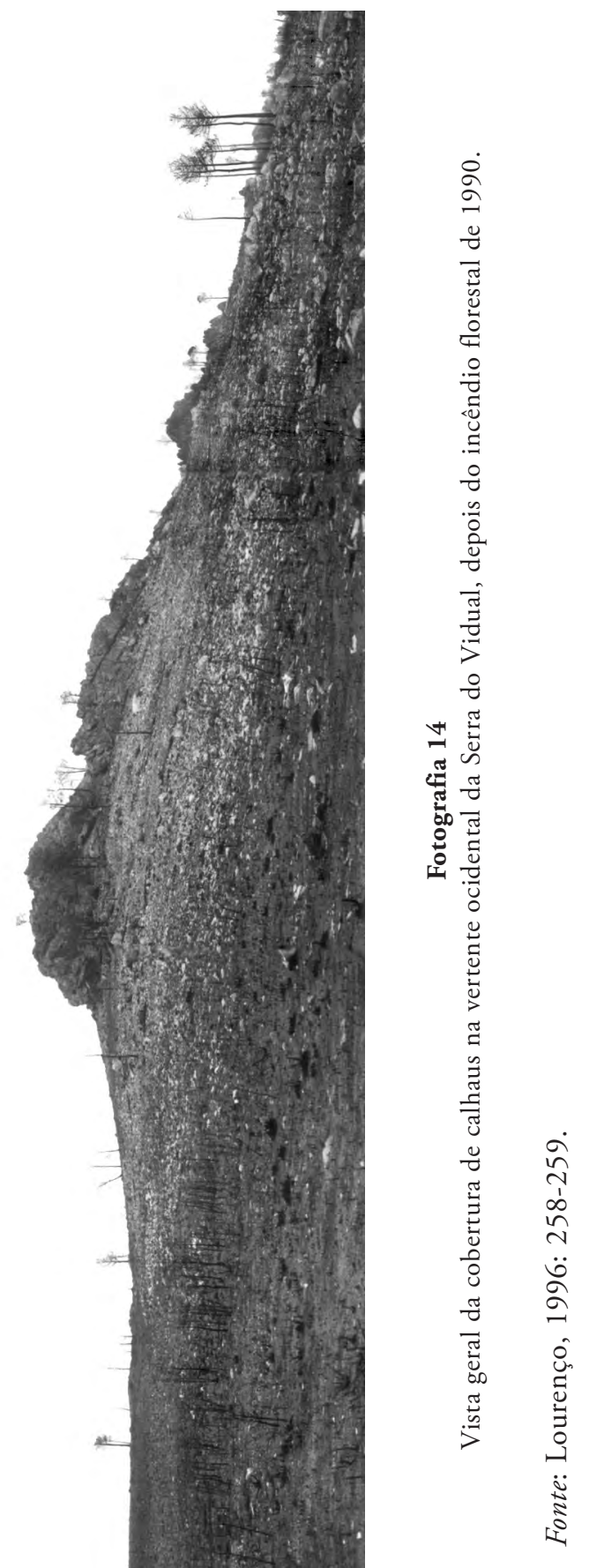




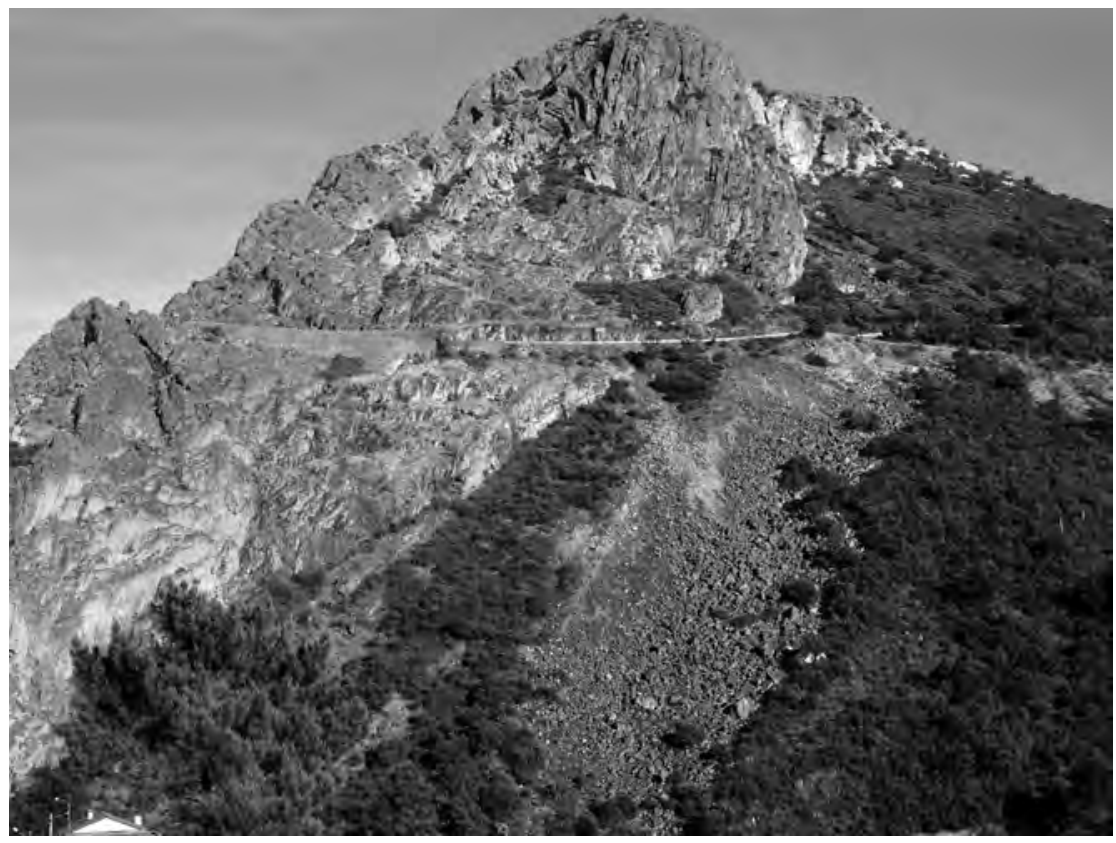

Fotografia 15

Aspeto da escombreira de gravidade que se desenvolve a expensas da crista quartzítica do Picoto.

Fotografia de L. Lourenço, tomada a 26 de agosto de 2015.

Constituem acumulaçôes de fragmentos quartzíticos, angulosos, heterométricos, sem matriz. A sua distribuição é irregular e a espessura parece pequena. Encontram-se em equilíbrio instável, apresentando grande mobilidade quando sujeitas a carga, pelo que a sua estabilidade nos parece duvidosa.

Embora haja indícios locais de terem funcionado recentemente, no conjunto elas serão devidas à atuação de processos periglaciares, sendo resultantes da gelifração ocorrida num período de frio mais intenso do que o atual, possivelmente no Tardiglaciar. 


\section{Conclusão}

O vale do médio Zêzere, em particular a montante de Álvaro, de onde era natural o António Gama, é um livro aberto em termos de geomorfologia estrutural, com destaque para a imponência e o didatismo das cristas quartzíticas que atravessam o vale, originando formas majestosas, bem como pela importância das falhas que delimitam o fosso tectónico, especialmente a Norte, onde são mais facilmente observáveis.

Do mesmo modo, também a geomorfologia dinâmica, bem como a climática, encontram neste setor diversos assuntos de grande interesse, a começar pelos meandros abandonados pelo pré-Zêzere, depois fossilizados com depósitos de cobertura, sobre os quais se reorganizou a drenagem, tendo deixado alguns deles bem conservados, como é o caso dos da Selada da Cova e da estrada de Fajão, fundamentais para compreender a evoluçáo geomorfológica do vale. Não menos interessantes são os magníficos meandros ativos, quer sejam profundamente encaixados, "de trincheira", com vertentes simétricas e abruptas, constituídos por sinuosidades de traçado rígido, quer sejam meandros "de dureza”, fortemente dissimétricos, com uma evolução rápida, que deixaram vários braços abandonados, como são os que se desenvolvem a montante do acidente tectónico da Abitureira.

Por estas e muitas outras razóes, o vale do Zêzere e, em particular, o seu setor intermédio, bem merecem uma visita detalhada, realizada com alguma minúcia, não só com objetivos geomorfológicos, de observação formas de relevo pouco comuns, com paisagens deslumbrantes, que fascinam todos quantos as descobrem, mas também será uma rara oportunidade para conhecer a humilde e simpática gente serrana, bem como para degustar a tradicional gastronomia e, simultaneamente, poderá ser, ainda, uma forma de recordar e homenagear a prestigiada figura do António Gama Mendes. 


\section{Referências bibliográficas}

Daveau, Suzanne; Birot, Pierre e Ribeiro, Orlando (1985/6). Les bassins de Lousã et d'Arganil. Recherches géomorphologiques et sédimentologiques sur le massif ancien et sa couverture à l'Este de Coimbra. Memórias. Centro de Estudos Geográficos, Lisboa, n. 8 (vol. I - Le bassin sédimentaire, 1985, et vol. II - L'évolution du relief, 1986), 450 p.

Instituto Geográfico e Cadastral. Carta de Portugal 1/100.000, Folha 20 - Covilhã (1974) e Folha 24 - Castelo Branco (1973).

Lourenço, Luciano (1996). Serras de Xisto do Centro de Portugal. Contribuição para o seu conhecimento geomorfológico e geo-ecológico. Dissertaçấo de doutoramento em Geografia Física, apresentada à Facudade de Letras da Universidade de Coimbra, Coimbra, 757 p.

Jaques Ribeiro, L. M. e Gonçalves, A. C. R. (2013). Contributo para o Conhecimento Geológico e Geomorfológico da Área Envolvente do Couto Mineiro da Panasqueira. Revista de Geografia e Ordenamento do Território, n. ${ }^{\circ} 3$ (Junho). Centro de Estudos de Geografia e Ordenamento do Território, pp. 93-116.

Ribeiro, Orlando (1949). O Fosso do médio Zêzere. Comunicaçōes dos Serviços Geológicos de Portugal. Lisboa, tomo xxx, pp. 79-85.

Soares, A. F.; Marques, J. F. e Barbosa, B. P. (1985). Visita a diversos lugares em estudo. Livro guia da pré-reunião, I Reuniāo do Quaternário Ibérico, Lisboa, pp. 84-100.

Soares, A. F.; Cunha, L. e Marques, J. F. (1993). Depósitos quaternários do Baixo Mondego: Tentativa de coordenação morfogenética. El Cuaternario en España y Portugal (Actas de la II Reunión del Cuaternario Ibérico, Madrid, 1989), Instituto Tecnológico GeoMinero de España, Madrid, vol. II, pp. 803-812.

Thadeu, Décio (1949). A Cordilheira Central entre as Serras da Gardunha e de S. Pedro do Açor. Boletim da Sociedade Geológica de Portugal. Porto, vol. viII, fasc. I-II, pp. 7-20. 